\title{
Social Hierarchies between Democracy and Autocracy
}

Björn Toelstede

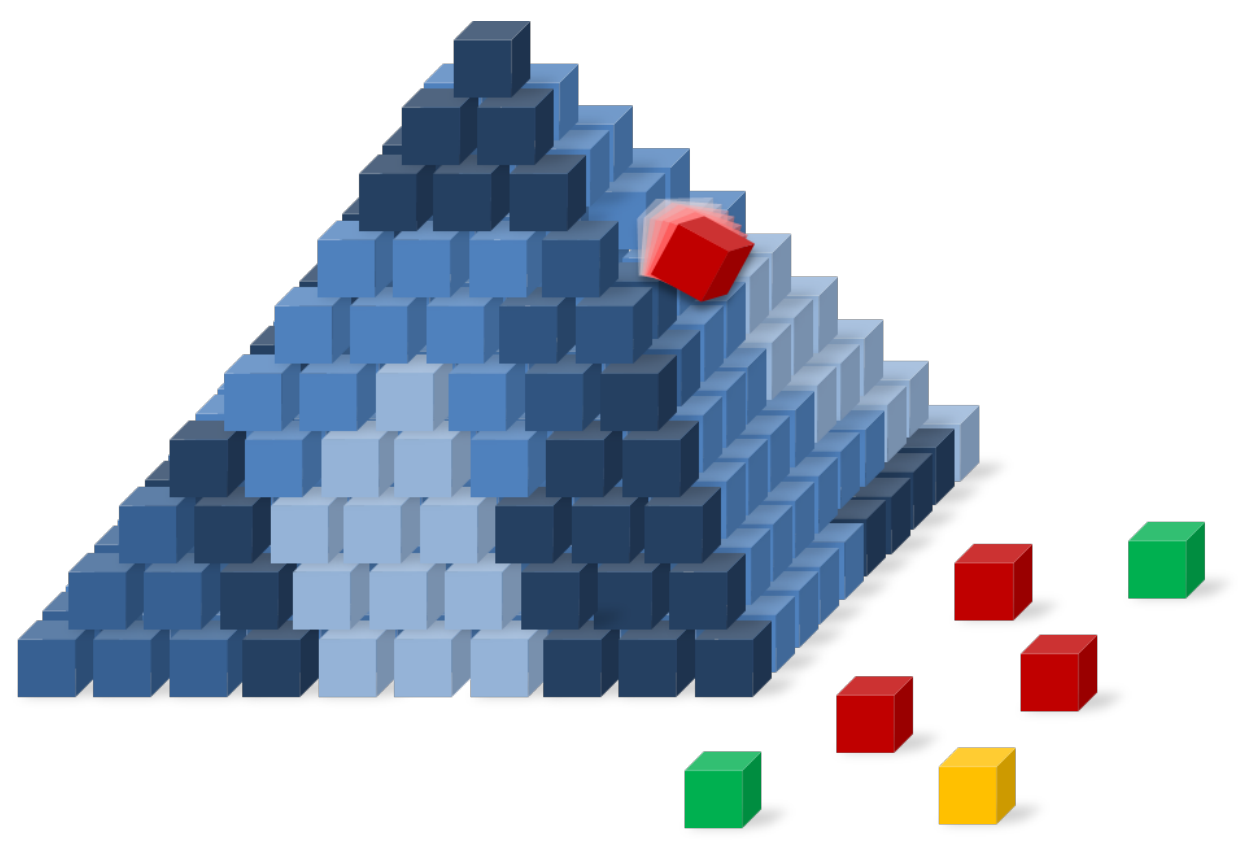





\title{
Social Hierarchies between \\ Democracy and Autocracy
}

\author{
Björn Toelstede
}

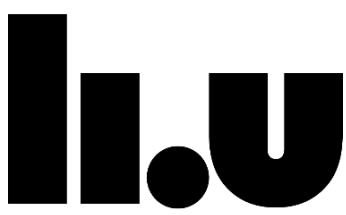

LINKÖPING UNIVERSITY

Department of Management and Engineering

Linköping University, SE-581 83 Linköping, Sweden

Linköping 2020 
(C) Björn Toelstede, 2020

Social Hierarchies between Democracy and Autocracy

Linköping studies in arts and sciences, No. 797

Published articles has been reprinted with the permission of the copyright holder.

Cover picture by Björn Toelstede

ISBN: 978-91-7929-749-7

ISSN: 0282-9800

Printed by LiU-Tryck, Linköping, Sweden, 2020

Distributed by:

Linköping University

Department of Management and Engineering

SE-581 83 Linköping, SwedenTel.: +46 13281000 
To my parents 

'If men were angels, no government would be necessary. If angels were to govern men, neither external nor internal controls on government would be necessary. In framing a government which is to be administered by men over men, the great difficulty lies in this: you must first enable the government to control the governed; and in the next place oblige it to control itself.'

The Federalist Papers

No. 51 (February 1788)

'All human authority, however organized, must have confined limits, or insolence and oppression will prove the offspring of its grandeur, and the difficulty or rather impossibility of escape prevents resistance.'

The Anti-Federalist Papers No. 3 (March 1788) 



\section{Table of contents}

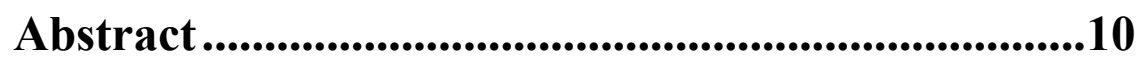

Abbreviations................................................................11

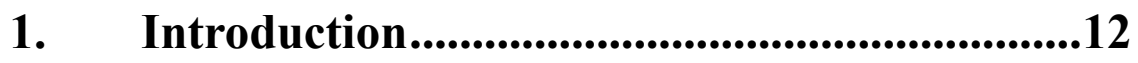

2. Methodology ..................................................17

3. Conceptual themes of the StructureBehavior Diagram............................................19

3.1. Definitions of power ...................................................... 19

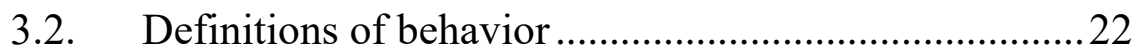

3.3. The real world's diversity in one model? ......................25

3.4. Considerations on the subsidiarity principal .................28

4. Path dependence and social hierarchies..........33

4.1. Path dependence degrees and foreseeability ……..........33

4.2. Bounded rationality .......................................................... 37

4.3. Political-economic aspects................................................ 38

5. The articles and their role within this thesis ..42

5.1. Article 1: Social Hierarchies in Democracies and Authoritarianism: The Balance between Power Asymmetries and Principal-Agent Chains ........42

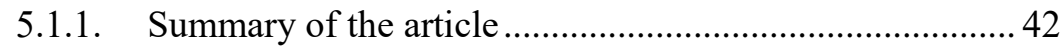

5.1.2. Discussion ................................................................. 42 
5.2. Article 2: How path-creating mechanisms and structural lock-ins make societies drift from democracy to authoritarianism

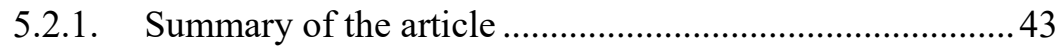

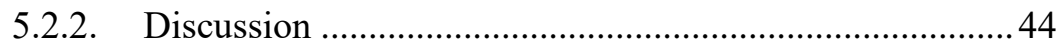

5.3. Article 3: Democracy Interrupted:

The Anti-Social Side of Intensified Policing ................ 45

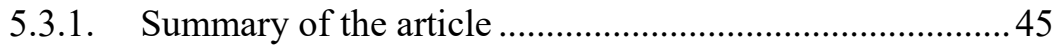

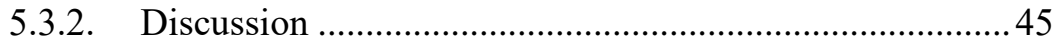

5.4. Article 4: The Absence of Policing and the

Political Economy of Contribution and Defection....... 46

5.4.1. Summary of the article ....................................................... 46

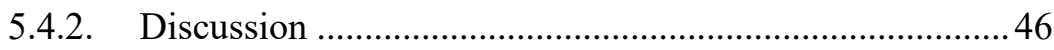

6. Conclusion............................................................48

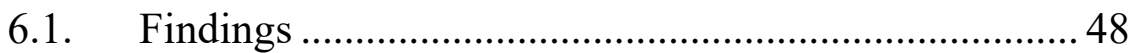

6.2. Further research ........................................................... 50

Acknowledgements ............................................................ 53

References.................................................................................. 54

The articles ............................................................................. 66 


\section{Abstract}

Social hierarchies exist in democracies as well as in authoritarian societies. However, their nature is different. Democratic hierarchies are built bottom-up through election, while autocratic hierarchies are built top-down through coalition formation and domination. Both have power asymmetries between the weaker citizens and the stronger politicians, which are amplified the stronger the hierarchies are. This thesis introduces a model which combines pro-/anti-social behavior with different degrees of hierarchies which I unite in a model called the Structure-Behavior Diagram (Toelstede, 2020/1). This model has the power to categorize countries according to these criteria, and indicates when and how societies move between democracy and authoritarianism.

The movements of societies in the political space of the Structure-Behavior Diagram are marked by certain patterns and dynamics. I use the path dependence theory (Toelstede, 2019/2) and examine how so-called path-creating mechanisms can emerge and influence societies to move from democracy to authoritarianism. I show that path dependency-induced dynamics can put democracies at risk and are more serious in hierarchical societies than in horizontal societies.

Institutional punishment is widely seen as more stable then peer punishment. However, in political reality, institutional punishment - here in the form of policing - can be marked by over- and under-punishment as well as changes in sociality (Toelstede, 2019/1 and 2020/2). These findings show, together with hierarchy-sensitive characteristics of the path dependency, that institutional punishment and social hierarchies require more attention.

Lastly, I show that most democratic societies are intuitively aware of the power asymmetries and long principal-agent chains between them and their political agents. Together, these features provide increasing benefits for an anti-social descent of the agents, although some societies are prepared to trade personal freedom for higher socio-economic welfare. They therefore strive for higher socio-economic efficiency by embracing strong governmental forms and high conformity levels. I call this efficient statism (Toelstede, 2019/2). In doing so, societies compliantly put their free and democratic order at risk. 


\section{Abbreviations}

$\begin{array}{ll}\text { ASP } & \text { Anti-social punishment } \\ \text { ASP }_{\text {inst }} & \text { Anti-social institutional punishment } \\ \text { ASP }_{\text {peer }} & \text { Anti-social peer punishment } \\ \text { CH } & \text { Coordination hierarchy } \\ \text { DH } & \text { Dominance hierarchy } \\ \text { E } & \text { Expansion path } \\ \text { GDP } & \text { Gross domestic product } \\ \text { GS } & \text { Government spending } \\ \text { NW } & \text { Network } \\ \text { P } & \text { Power } \\ \text { PA } & \text { Power asymmetries } \\ \text { PAI } & \text { Power asymmetries indicator } \\ \text { PCM } & \text { Path-creating mechanism } \\ \text { PF } & \text { Personal freedom } \\ \text { PSP } & \text { Pro-social punishment } \\ \text { PSP } & \text { Pro-social institutional punishment } \\ \text { PSP } & \text { Pro-social peer punishment } \\ \text { PUN } & \text { Punisher } \\ \text { RP } & \text { Reciprocal power } \\ \text { r\&p } & \text { Reward and punishment } \\ \text { SBD } & \text { Structure-behavior diagram } \\ \text { SEO } & \text { State of emergency } \\ \text { SON } & \text { State of nature } \\ \text { SQF } & \text { Stop and frisk } \\ T_{\text {ind }} & \text { Individual tolerance limits } \\ T_{\text {soc }} & \text { Social tolerance limits } \\ \text { W } & \text { Welfare } \\ W_{\text {ind }} & \text { Individual welfare } \\ W_{\text {soc }} & \text { Social welfare } \\ & \\ & \end{array}$




\section{Introduction}

Strong democratic institutions are widely seen as bulwarks against authoritarianism. Humans prefer hierarchies (Nicklisch et al., 2016; Tiedens et al., 2007; Tiedens and Fragale, 2003), considering them to be more stable (Demange, 2004; Friesen et al., 2014). Sometimes, it is argued that social hierarchies are the only viable instrument to cope with the tragedy of the commons (see Ostrom, 1990: 8ff. for a collection of prohierarchy advocates in the 1970s and 80s). Hierarchies are supposed to be more efficient than horizontal structures at coordinating the daily problems of a society (Halevy et al., 2011; Ronay et al., 2012; Lim and Zhang, 2020). Even when people are about to tear down an existing political hierarchy, they paradoxically claim the immediate need for a new hierarchy. In 2014, Hong Kong's streets were taken over by the umbrella movement, demonstrating against the strongly hierarchical system remote-controlled from Beijing. Critics regarded the uprisings as having failed, because the protestors' organization had 'no clear hierarchical chains of command' (Tharoor, 2014). This shows that when it comes to managing public affairs, we almost automatically think in terms of hierarchical structures.

This viewpoint can be elusive. Strong democratic institutions create long and complex principal-agent chains between citizens (the principals) and politicians (their agents). These chains are marked by power asymmetries between the stronger politicians and the weaker citizens. They make societies vulnerable to adverse selection and moral hazard. However, what is good for coordination and welfare creation can also be good for the abuse and oppression of people. Or, in other words, 'the state can be simultaneously the most efficient and most dangerous tool under human control' (Dubreuil, 2010: 230). Power asymmetries and long principal-agent chains provide increasing benefits of anti-social descent for the agents. Once the latter are broken, the former enable the agents to reign unchecked. Moreover, peer punishment among elites might not always prevent this descent since all elite members are, in principle, equally exposed to the appealing incentives of anti-social descent. On the contrary, in societies without power asymmetries, nobody has enough power to subdue others. Hence, there are few benefits of anti-social descent.

Political science has already dealt with the question of sociality and verticality. Recent approaches focus on either the distinction between hierarchical/horizontal societies or the pro-/anti-sociality of the same. They describe social hierarchies as ambivalent (Van Vugt et al., 2008), and divide them into productive and dominance hierarchies (Rubin, 2000) or functional and dysfunctional hierarchies (Anderson and Brown, 2010). Further, they distinguish between two behaviors such as dominance and prestige (Henrich and Gil-White, 2001). Democracies tend to reward prestige and punish dominance, while authoritarian systems do the opposite. Magee and Galinsky (2008: 21f.) define hierarchies as differentiation across individuals or groups on any 
(commonly) valued dimension'. For Lake (2009: 264), hierarchies are any form of social differentiation and stratification as well as differences in authority over others (here: power asymmetries). So, all these approaches distinguish between either proand anti-sociality or hierarchical and non-hierarchical societies. The combination of both, the degree of pro-sociality and the degree of social hierarchy, can be found in Aristotle (2009: 100f.). He distinguished between governments whose objective is the 'common interest' (pro-social) and those who are 'directed to the [selfish] interest' (anti-social). Further, he defined three degrees of social hierarchy, ranging from nonhierarchical to strongly hierarchical. In short, he combined different degrees of power asymmetries with the pro- or anti-social use of power. The combination of these two dimensions is the center of this thesis.

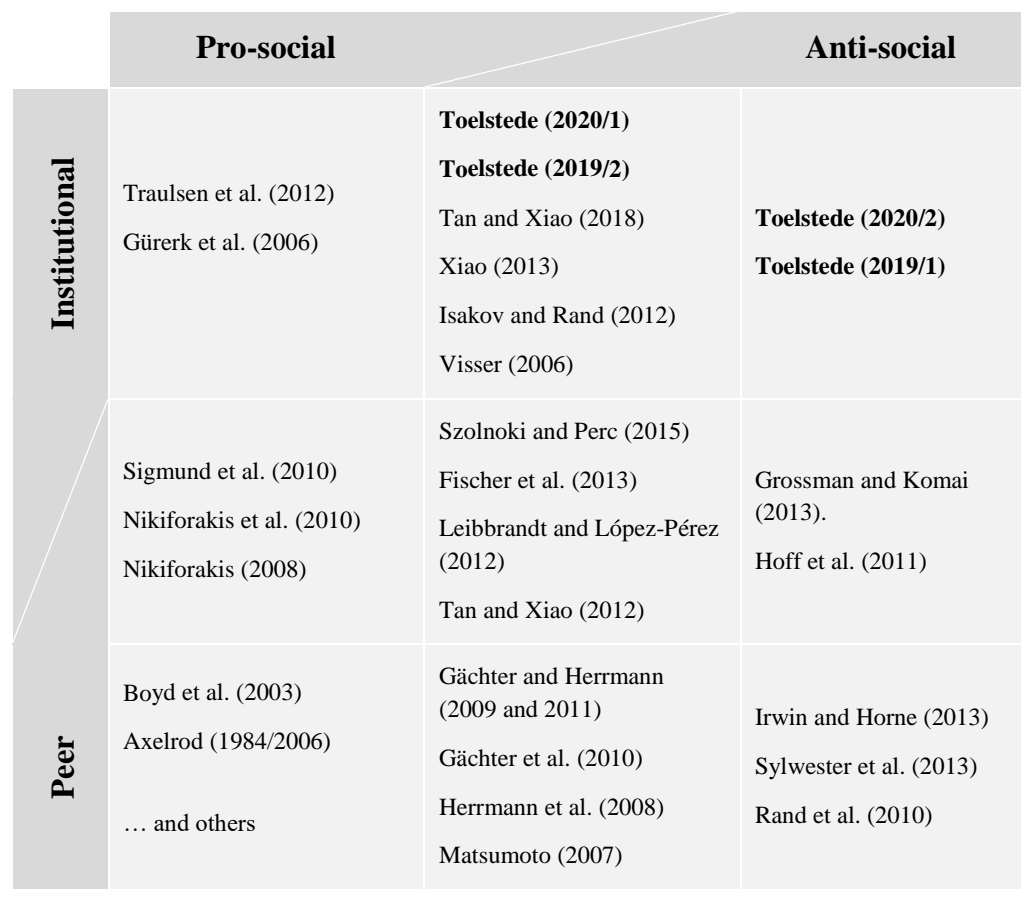

Figure 1. Examples of studies combining peer and institutional punishment, as well as pro- and anti-social punishment.

Behavioral science has also dealt with the question of sociality and verticality (i.e. the distinction between peer and institutional punishment). As illustrated in Figure 1, behavioral science started with the analysis of pro-social peer punishment. It then slowly developed into anti-social peer punishment and pro-social institutional punishment. The approaches slowly fade out toward the upper right corner, where anti- 
social institutional punishment can be found. This is the area on which this thesis concentrates. Anti-social institutional punishment can appear in different forms, like coalition formation, social dominance, bureaucratic instruments, or legal or social constraints (e.g. the structural lock-ins in Toelstede, 2019/2), but also results from the use of security forces. In two articles (Toelstede, 2019/1 and 2020/2), I examine the possible anti-sociality of institutional punishment in the form of policing. Policing is a key instrument of any government to enforce rules in a society. I analyze two situations. The first is over-policing (over-punishment) in reaction to terrorist acts (anti-social shock). The second analyzes the sudden absence of policing (underpunishment) and democratic dynamics. In most cases, societies find their way back to normality. However, I show that these occurrences can harm societies.

There is a discussion about whether modern internet society will crumble traditional hierarchical structures (Gardels, 2012). They do have an impact, but hierarchical and authoritarian social structures are still present in the political landscape. Vertical social structures even emerge in online social networks (Gupte et al., 2011). Our behavior is (still) influenced by the existence of vertical social structures and the incentives they embrace (Pfeffer, 2013). So, despite all the trends of flat hierarchies, networks, and market economies, we still have an affinity for social hierarchies - 'we are still the same' (ibid.). This thesis is marked by a certain skepticism regarding whether hierarchical structures are always the best choice for resolving social problems. I rather advocate that societies tacitly accept risks of power usurpation when escalating too many social problems to the government.

I show that the strength of social hierarchies, corresponding to the level of power asymmetries, plays an important role in the movement of societies between democracy and authoritarianism. I depart from a behavioral science perspective and combine this with political science. I abstract from a couple of political institutions and terms (e.g. political organizations, constitutions, elections, parliament, government, military, etc.). Nevertheless, I regularly cross over to the political world, especially when including contemporary real-world examples in the text.

The key model for addressing these questions is what I label the Structure-Behavior Diagram. This results from the distinction between hierarchical and non-hierarchical societies on one side, and pro- and anti-social behavior on the other. In this "political space", societies can float between authoritarianism and democracy. However, in contrast to a single-dimensional democracy-authoritarianism distinction, the model shows the strength of the social hierarchies present in societies. This allows us to demonstrate that movements of societies between these political setups significantly depend on the strength of their social hierarchies (i.e. their verticality). Further, I present self-enforcing mechanisms which generate path dependencies in societies and can cause them to slip into authoritarianism. For that purpose, I make recourse to the path dependence theory introduced by Paul David (1985) and further developed by others over the years. I have modified the idea for the purpose of this topic, making it applicable to the dynamics of political structures. Therefore, I have used the 
organizational path dependence theory of Sydow et al. $(2009,2020)$ and the 'pathcreating mechanisms' of Beyer (2010).

My approach is interdisciplinary. The model combines microeconomics, behavioral economics, socio-biology, anthropology, social ontology, political economy, and political science. This implies different terminologies, diverging basic convictions, and analytical patterns following on from the different science traditions. To deal with this, I use interdisciplinary terms knowing that switching between disciplines is not without the risk of causing confusion. It requires precaution and accuracy. Behavioral science has shown that most people have a predisposition for cooperation and are ready to punish those individuals who do not cooperate. The people are ready to assume the punishment costs privately without any personal advantage (altruistic punishment) (Fehr and Gächter, 2002). In an experiment conducted by Fehr and Gächter (1999/2000), eight out of ten test groups which were allowed to engage in altruistic punishment converged on 'almost full cooperation' (ibid.). And yet the mere existence of a credible threat of possible punishment promoted cooperation (ibid.). But if humans are that 'cooperative species' (Bowles and Gintis, 2011), why is it that history is marked by violence, oppression, and authoritarian regimes? ${ }^{1}$ Indeed, humans have been very successful whenever they have chosen to cooperate with each other. Nevertheless, these cooperative arrangements have been regularly interrupted by authoritarian and violent phases.

The Structure-Behavior Diagram is composed of four society types. I call the first pro-social - realization of vertical social structures coordination hierarchy, and the second - the anti-social one - dominance hierarchy. Vertical social structures are marked by power asymmetries; the strength of these asymmetries defines the level of verticalization. Coordination hierarchies are vertical social structures resulting from the escalation of coordinative tasks from the citizens to their political agents - bottomup. On the other side, I define those vertical social structures which result from malicious coalition formations of individuals aiming to abuse and oppress other individuals - top-down - as dominance hierarchies. In this model, pro-social societies resemble the idea of democracies whereby not all real-world democracies are as prosocial as they claim to be. Pro-social societies correspond to 'effective democracies' (Inglehart and Welzel, 2005). By contrast, dominance hierarchies resemble authoritarian regimes.

In addition to the two vertical social structures, there are two horizontal ones. Network (or network society) shall be defined as a horizontal social structure of individuals who pro-socially coordinate public affairs. It is the non-hierarchical counterpart to the

\footnotetext{
${ }^{1}$ Even though both Pinker (2011) and Scully (1997) have observed a decline in global violence. Pinker has conducted a time serial analysis over hundreds of years, and Scully has carried out a regression analysis finding a negative correlation between violence and personal income. As income increases over time, violence should decrease. However, Mexico, for example, experienced a decline in homicides between 1930 and 2008 from 65 to 9 per 100,000 citizens, but in just three years from 2008 to 2011 it witnessed an increase to 24 per 100,000 (Krauze, 2015).
} 
coordination hierarchy. In both, pro-social behavior is predominant. The remaining type will be called state of nature, and is the non-hierarchical counterpart to dominance hierarchies. In both, anti-social behaviors are predominant. Societies do not only move between pro- and anti-sociality as they do in a one-dimensional DemocracyAuthoritarianism perspective. They can also change their levels of hierarchical order, their power asymmetries. Moreover, we will also see that societies' movements between democracy and authoritarianism are different depending on the strength of their hierarchical structures. Further, their movements between democracy and authoritarianism often involve changes in their hierarchical order. 


\section{Methodology}

This thesis is a conceptual analysis of social hierarchies in democratic and nondemocratic regimes. I approach the theme in a largely deductive manner, before using empirical analysis to (preliminarily) confirm or reject the theoretical postulates. Studies about authoritarianism and, to a lesser extent, anti-social actions in democracies need to be rationally very solid and protected from several sides. This is for various reasons. First, any model dealing with politically sensitive topics can be attacked from an ideological or teleological side by questioning the viewpoint of its basic socio-political assumptions and alleged purpose. To avoid this, I frame the model in such a way that it allows the occurrences in the political space between democracy and authoritarianism to be discussed from different ideological viewpoints. So, it is not the model itself which discriminates between certain political viewpoints, but the debate which the model enables.

The second reason is that it is difficult to find good empirical data. As always, the data must properly reflect explanans and explanandum. It needs to be available in terms of quantity, reliability, and continuity. The reliability and completeness of empirical data on a global level is already a challenge in politically non-sensitive areas. Hence, when it comes to security-related data or the potential malfunction of governmental institutions like over- or under-policing, anti-social effects of political actions (Toelstede, 2019/1, 2020/1 and 2020/2), or authoritarian regimes (Svolik, 2012), the situation becomes difficult. It is not in the political agents' interest to be properly evaluated by civilian principals. The quantity and quality of available data quickly fades away, and there is a possibility that empirical data will be biased, leading to incorrect conclusions. So, the empirical work in this area is complicated. Sometimes, as in Articles 3 and 4 (Toelstede, 2019/1 and 2020/2), it is a matter of using the opportunities offered by apparently unbiased and complete data from events in the political reality.

Another possibility for overcoming this problematic is to use politically non-sensitive data which is less likely to be biased, and has better completeness and greater availability. I do this in Article 1 (Toelstede, 2020/1), with government spending relative to GDP as an indicator of societies' verticality. Nevertheless, in doing so, I trade explanans/explanandum quality for empirical data quality. In other words, the data availability in terms of quantity and quality increases, which makes the correlations more robust. On the other hand, the data used loses explanatory quality as it does not exactly resemble the problematic. It provides higher robustness but lower necessity in indicating a causal relationship. This difficulty in relation to the empirical data quality makes it even more important to have a firm conceptual model.

This interdisciplinary approach implies different methodologies and terminologies, which could limit their compatibility. For instance, some research directions pursue methodological collectivism while others prefer individualism. I respect these 
methodologies and carefully connect them with reductionism and emergentism (ElderVass, 2010). The same goes for the diverging terminology used by different disciplines. This study is mainly about political and social science, behavioral and game theory, economic science, social ontology, and psychology. I sometimes switch between terminologies to bridge the gap between the different faculties.

The core element of this approach is the Structure-Behavior Diagram (Toelstede, 2020/1), which distinguishes between pro- and anti-social behaviors as well as hierarchical and non-hierarchical societies. Both dimensions require a thorough theoretical definition, allowing the two to be combined into one model and the countries to be categorized. The pro-/anti-sociality distinction in the StructureBehavior Diagram entails the risk of falling into subjectivism or applying a moral imperative. My pro-sociality definition departs from the individuals' consensual judgement of what is good or bad, and not from the perspective of a social planner. I define pro-sociality as a situation of '... dialogical morality, where all the affected parties have a voice in an open dialogue...' (Wenzel et al., 2008: 385), following Habermas' discourse ethics (Habermas, 2009). This is based on a dialogue between equal participants who morally constitute and legitimize the rules of a society. Since every individual is presumed to be able to participate in this social dialogue, it is fair to consider the resulting rules as pro-social.

In contrast to this individualistic and purely bottom-up approach, there is a collectivistic and partly top-down perspective. I show that part of what I call efficient statism (Toelstede, 2019/2) involves harmonizing or manipulating the individual's perception, consensual evaluation, and judgement of social situations. Societies which apply this concept pursue an ambiguous and fallible ambition to achieve higher socioeconomic welfare results by giving up individual freedom. 


\section{Conceptual themes of the Structure-Behavior Diagram}

\subsection{Definitions of power}

When writing about social hierarchies and their possible negative aspects, like abuse and oppression, it is necessary to make some considerations about power. The term is ubiquitously used and often not well-defined. Apart from power itself, we can observe a variety of similar terms (e.g. constraints, violence) expressing the situative or contextual variances. I present a selection of these power concepts which are relevant for this analysis.

Besides the negative connotation which the term has in popular social discussion, there are also positive accounts in the literature. One of them is Han (2005), for whom power is the ability of A to convince B to do what A wants him to do and B does it out of conviction. To achieve this, power needs to be 'conveyed' (ibid.). Violence, in turn, is the 'unconveyed' (ibid.) form of power. Han distinguishes between power and violence by the grade of conveyance with which they are communicated. According to Han, only the one who is poor in power needs to apply authoritarian means (i.e. violence).

To assess individual actions, a power concept is required which allows the power of a given political regime to be separated from the power each regime member has. The difference between all members' power and the total regime emerges from the social structure connecting them. To begin with, I take the power definition of Max Weber who said: 'Power means any chance, within a given social relation, to enforce one's own will on somebody else, despite his aversion and independently from where this chance derives from. ${ }^{2}$ Individuals can have power over other individuals. In a social hierarchy, every individual has power over the lower ranked. But part of this power is derived from the next higher ranked person. Thus, the actual net power of an individual is much smaller than it might be perceived to be by his subordinates. Consequently, social hierarchies follow from a huge net power equation between the individuals composing it. However, the power which is exerted over an individual in a social hierarchy also follows from the collective power exertion of all superiors - in the form of an (un-)conscious parallel behavior. I will come back to this. In my approach, the terms reward and punishment will play important roles. Both are fundamental coordination tools of societies. Reward and punishment are realizations of power. Further, power asymmetries (PA) result from differences in the reward and punishment power $(\mathrm{P})$ the individuals have over each other (Equation 1). If PA is positive, $\mathrm{A}$ has

\footnotetext{
${ }^{2}$ Weber (2006) p. 62. (German original): "Macht bedeutet jede Chance, innerhalb einer sozialen Beziehung, den eignen Willen auch gegen Widerstreben durchzusetzen, gleichviel worauf diese Chance beruht."
} 
more power over B; if it is negative, B has more power over A. An (authoritarian) regime should start to crumble when the net power in this equation becomes negative, if we assume $\mathrm{B}$ to be lower ranked than $\mathrm{A}$. If $\mathrm{PA}=0$, we speak about a horizontal society; if $\mathrm{PA} \neq 0$, we speak about a hierarchical society. Only in horizontal cooperation are the mutual net powers symmetric.

$$
\mathrm{P}(\mathrm{A} \text { over } \mathrm{B})-\mathrm{P}(\mathrm{B} \text { over } \mathrm{A})=\mathrm{PA}
$$

Equation 1. The power asymmetries resulting from power difference between two individuals.

Another power term is reciprocal power (RP), which describes the inner strength of the relationship between individuals. It follows from the sum of two individuals' reward and punishment power in this simple bilateral equation. The sum of the mutual reward and punishment power $(\mathrm{P})$ of all individuals describes the inner rigidity of a society. The sum of reciprocal powers in a society $\left(\sum R P_{i j}\right.$ of all individuals $i$ and $j$ ) describes the 'structural lock-in' (Toelstede, 2019/2) of a society. Reciprocal power exists in symmetric or horizontal $(\mathrm{PA}=0)$ as well as asymmetric or hierarchical relations $(\mathrm{PA} \neq 0)$.

$$
\mathrm{P}(\mathrm{A} \text { over } \mathrm{B})+\mathrm{P}(\mathrm{B} \text { over } \mathrm{A})=\mathrm{RP}
$$

Equation 2. The reciprocal power between two individuals.

I call all these powers natural powers. Moreover, there are structural constraints which are often used to explain the limiting effect of social structures (e.g. social milieu, culture, religion, or idiosyncrasy) on the individuals' behavioral options. In this case, there is no person who forces another one to do something. The idea of structural constraints is a collectivistic concept and, thus, it needs to be broken down to make it manageable for behavioral science. One concept which helps to explain where these constraints come from is that of 'deontic powers' (Searle, 1995 and 2010). It describes the 'rights, duties, obligations, requirements, permissions, authorizations, entitlements and so on' (Searle, 2010: 9) which an individual has toward other individuals or society.

Deontic powers are based on 'status functions' (Searle, 1995), which derive their virtues from the collective intentionality of the respective society. Collective intentionality attributes status functions to entities and, with them, deontic power over all individuals related to them. For example, a police officer derives the functional power to carry out his job according to rules from an officer ID. The ID has been given to the officer by somebody who has been given entitlement (by somebody else) to 
declare this person a police officer. This officer ID, and with it the functional powers, can be retrieved by somebody else (e.g. a judge) who, in turn, has been empowered by somebody else to do so. This example could be continued infinitely. Deontic powers differ from the previously mentioned natural powers in that they do not follow directly from the individual's personal capabilities but from the powers attributed collectively to the individual. Political institutions are based on numerous deontic power relations within and between them. So, deontic powers are a reducing concept to institutions in the sense of Searle (2005), which allows to abstract from political institutions without excluding them from the analysis.

Society collectively imposes 'functions on objects and people where the objects and people cannot perform the functions solely in virtue of their physical structure' (Searle, 2010: 7). Whether this involves peer relations or the anatomy of social institutions, it can be traced back to these concepts. The status functions and the related deontic powers in a society change with the altering behavioral, structural, and normative characteristics of a society. For instance, when a political regime breaks down, many status functions and the related deontic powers cease to exist; a king is no longer regarded as a king, a minister no longer as a minister, and so on. Natural and deontic powers can cause what I refer to as a structural lock-in (Toelstede, 2019/2). This term describes a situation where individuals are stuck in a social structure with little or no freedom to maneuver. While structural constraints is a collectivistic sociological term, structural lock-in aims to break down, model and quantify the implicit freedom-limiting powers. It is a collectivistic interpretation of a situation which makes the situation cumbersome to evaluate. The concept of structural lock-in does not stop there - it breaks down further.

In this study, I apply both methodological individualism and collectivism. This makes it possible to address situations where the individual's behavior triggers changes in the group and situations where the social environment influences the individual's behavior. Methodological individualism is mainly used by economists and gametheorists, while collectivism is rather used by sociologists and social ontologists. The methodological connection between the two schools is the reductionism which offers a toolbox to reduce seemingly collectivistic phenomena to an individualistic level. In the opposite direction, from individualistic to collectivistic level, I apply the concept of emergentism (Elder-Vass, 2010). However, some social ontologists question reductionism and emergentism (e.g. Searle, 1995 and Tuomela, 2013). Certainly, this needs to be done with caution to avoid losing important aspects along the way, or wrongly connecting alleged causes and effects.

Structural lock-ins emerge from the multiple natural and deontic powers present in a society (Equation 3). These powers have both resulting and emerging aspects. Resulting powers are simply summed up and are in line with methodological individualism. Emerging powers (expressed by the function $f$ in Equation 3) describe those powers following from power attribution by collective intentionality, in line with methodological collectivism and the abovementioned collective power exertion. The 
collective exertion has an emerging effect in the form of a de facto legitimacy for the exerted actions, although this does not imply a moral legitimacy. It can also follow from the unconscious parallel behavior or tacit consent. This means that emerging powers are more than the sum of the individual actions. Structural lock-ins have a resulting and an emerging component (Equation 3).

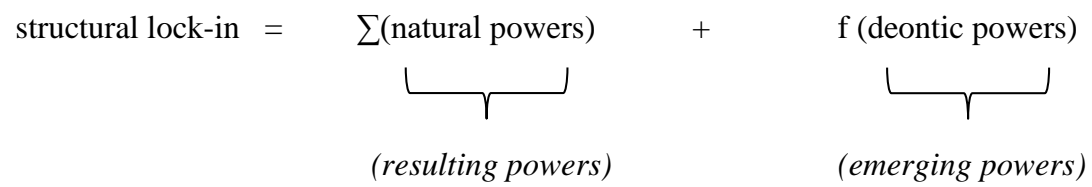

Equation 3. The structural lock-in following from of all natural and deontic powers in a society.

To calculate the power asymmetries between two groups, we need to calculate the net power for the natural powers. We then need to define the difference between deontic powers empowering or disempowering each of the groups or individuals in the equation. This includes defining the differences in emerging powers following collective power exertion of the two groups. This is of importance when thinking about a power asymmetries indicator. This indicator would measure the strength of the hierarchical structures in a society, and therefore needs to take all natural and deontic roots into account. To summarize, the power definitions of Weber and Han for natural power and those of Elder-Vass and Searle for deontic power provide the conceptual basis for my approach.

\subsection{Definitions of behavior}

Here, I define the behavioral terms which are relevant for this approach, namely proand anti-social, reward and punishment, coordination and abuse and oppression. Individual behaviors have a high influence on societies' movements between freedom and oppression. To cope with daily problems and to promote socio-economic development, the individuals in a society must reach a consensus on how to allocate resources, how to organize social and economic transactions between them, and how to distribute the fruits of their work. This process shall be called coordination. The idea of coordination to organize economic transactions between people is in line with Williamson's (1975) transaction costs theory. However, I extend the term to noneconomic transactions, in other words social transactions. Thus, it comprises all transactions needed to make a society work. In the case of private goods without any public good character or external effects, the individuals act independently. In the case of public goods, the individuals coordinate their activities, taking allocational and distributional aspects into account. They agree on how much each party must 
contribute, how much it will receive, and how to deal with free-riders and defectors. Managing public goods has been intensively discussed by behavioral and economic science.

Further, I use the two concepts of reward and punishment ( $r \& p$ ), tracing back to Adam Smith (2010/1759). In their daily interactions, individuals reward good behaviors and punish bad ones (Almenberg et al., 2011; Nikiforakis and Mitchell, 2014). The realization of punishment ranges from signaling discontent or disagreement, via hindering the other party from doing something, to the use of coercive or punitive measures. Reward works in the opposite direction. The individual's behavior, and especially reward and punishment, can be pro- and anti-social. The possibility of antisocial behavior in the form of abuse and oppression is the opposite of the pro-social coordination in this model. I use this term to describe societies in which the malicious intention of some to increase their welfare level at the expense of others is the predominant behavior (similar to Magee and Langner, 2008).

Figure 2 makes a comparison between the effects of an individual's behavior on his own welfare and on society's welfare. The individual's welfare is shown on the vertical axis, while society's welfare is displayed on the horizontal axis. I apply a broad welfare notion going beyond the monetary welfare concept of economics; it includes material and immaterial welfare, the freedom of the individual, human and civil rights, safety, the possibility of self-determination, and self-actualization. The relative importance of these realizations can vary within and between cultures. Starting from point $t_{0}$ in Figure 2 , the individual's actions cause a move to the right and increase society's welfare. In a meritocratic society, all individual contributions to society's welfare (a move to the right) are recompensed to the individual (an upward move). These recompenses can occur in many ways, such as honor, social status, goods or pecuniary forms like salaries, profits, or interest. So, ultimately, the welfare of society and the individual increase. The ratio between social and individual welfare remains constant along the expansion path $\mathrm{E}$. I now widen this strict relation. $\mathrm{T}_{\mathrm{soc}}$ and $\mathrm{T}_{\text {ind }}$ represent the tolerance limits of the society or the individual, respectively. Within this tolerance vector, the range between $T_{\text {soc }}$ and $T_{\text {ind }}$, a society can develop without facing major frictions regarding welfare distribution. This model can also be used to describe the welfare distribution between different groups within a society. Passing one of the tolerance limits can provoke frictions in a society. Further, the model allows us to compare an individual with the next higher or lower ranked individual in a social hierarchy. It can also be used to analyze two groups of a stratified social hierarchy competing for the distribution of welfare and the relative social ranks.

AR in Figure 2 represents the activity range (corresponding to the utility possibility frontier in economics) of the individual. He can spend his resources on activities that increase either society's welfare (a horizontal move) or solely his private welfare (a vertical move). In a society with functioning pro-social r\&p mechanisms (a meritocratic society), it does not matter what actions the individual takes. Horizontal moves would be rewarded by society, resulting in a consecutive vertical move. Vertical 
moves would be punished - e.g. by taxation of revenues - if they are linked to noncontribution to public goods, disproportional receipt of public goods, or negative external effects. In the end, all individuals' actions in a society with a functioning r\&p system should cause a move along the path $\mathrm{E}$ or within the tolerance vector $\mathrm{T}_{\text {soc }}-\mathrm{T}_{\text {ind }}$ in Figure 2.

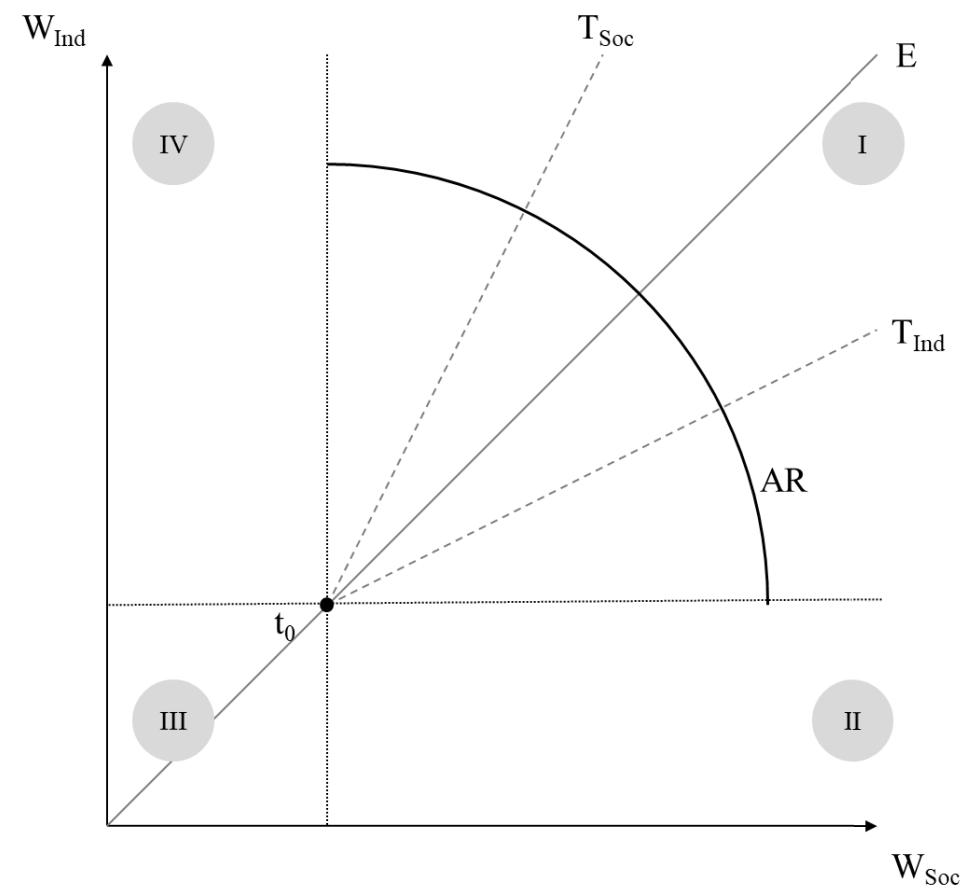

Figure 2. Individual versus social welfare.

When it comes to social ranks in hierarchies, the situation is different. An individual can increase his personal welfare without necessarily lowering society's welfare. However, he cannot increase his social rank in the social space (Bourdieu, 1984) without lowering the relative rank positions of all others. This is because the value system of social rank is a zero-sum equation. Social rank systems are part of hierarchical societies. And we all live in hierarchical societies in some way. They offer individuals the opportunity to spend their resources solely to improve their own social rank, without contributing to public goods. This is a kind of social rent-seeking with a destructive effect on social welfare (Ahn et al., 2011: 18). As De Tocqueville (2011: 123) wrote, 'the ambition of the citizens increases with the power [meaning: the verticality or the hierarchy] of the State'. He thereby distinguished between the concepts of productive and social rent-seeking actions. De Tocqueville argued that in 
the American republics, in comparison to the European countries of his time, the 'ambition of power [in Europe] yielded to the less refined and less dangerous love of comfort [in America]' (ibid.: 125). Today, the inclination for rank-seeking differs between societies and individuals. Conservatives, for instance, are more prone to carry out vertical activities then liberals (Ordabayeva and Fernandes, 2018).

Another important factor is natural resources. These have been extensively discussed in literature as being the source of non-productive revenues which help regimes to stay in power for longer (e.g. Wright et al., 2015). The revenue is independent of individual productive actions. Beyond the well-known Dutch disease effect of decreasing investments and increasing consumption, natural resources foster social conflicts. They are common goods with consumption rivalry but limited excludability. In societies which rely on natural resource revenues, this excludability is achieved by rules (which are not always respected) or ultimately by arms. Thus, natural resource revenues 'become a type of "honey pot" in which competing interests try to capture a significant part of resource rents by capturing portions of the state' (Karl, 2007: 666). Natural resources are a permanent apple of discord in the political arena of a society. They stimulate a culture of rivalry where everybody tries to increase his welfare or social rank at the expense of others. This culture can also emerge in societies with large state-protected monopolies. These monopolies generate super-normal profits which are similar objects of rivalry to natural resources. Lastly, the individual's behavior is influenced by the environment, which 'determines whether the fair types or the selfish types dominate' (Fehr and Schmidt, 1999). Especially in the case of a stagnating or shrinking economy, people try to defend their individual welfare level and social ranks. That might result in an increase in rivalry and defection, punishment and counter-punishment, with higher conflict expenditures (Casari and Luini, 2009; Nikiforakis and Engelmann, 2011; Fehl et al., 2012).

\subsection{The real world's diversity in one model?}

The world is characterized by different cultures, ideologies, preferences, etc. This diversity might generate different behavioral patterns in reaction to the same stimuli. A large amount of literature has approached these cultural differences. There are studies about the readiness to assume the costs of peer punishment (Henrich et al., 2006) and the trust level differences influencing the effectiveness of peer punishment (Balliet and van Lange, 2013). Further, they examine sensitivity to economic r\&p incentives (Henrich et al., 2005), the propensity for anti-social behavior (Gächter and Herrmann, 2009 and 2011; Gächter et al., 2010; Herrmann et al., 2008; Matsumoto, 2007), and models to measure these differences (Fehr and Fischbacher, 2004). Some authors have analyzed neurobiological aspects to predict differences in behavioral patterns (Farrow et al., 2011), while others have paid attention to genetic influences (Edsall, 2014) or historic pathogen prevalence (Fincher et al., 2008; Murray, 2013; Murray et al., 2013) in our political beliefs. Scholars have analyzed traditionalism, 
conservatism, and liberalism. They see traditionalism as one of the key drivers of people's readiness to obey authorities (i.e. social hierarchies) (Bouchard in Voland and Schiefenhövel, 2009: 165-188). Henningham (1996) measured the grade of social conservatism, and according to Graham, Haidt, and Nosek (2009), liberals and conservatives rely on different sets of moral foundations. In contrast to conservatives, liberals pay significantly more attention to reciprocity, which is important for cooperation and peer punishment. Further, liberals pay less attention to values such as respect for authority, purity, and sanctity, which are fundamental to the promotion and acceptance of hierarchical social structures (ibid.). So, in a heterogenous context, we should be aware that there may be different interpretations of what is regarded as being pro- and anti-social.

\begin{tabular}{|c|c|}
\hline Individualistic societies & Collectivistic societies \\
\hline $\begin{array}{l}\text { - Rather self-regarding (Gintis, 2013) } \\
\text { - I-mode predominant (Tuomela, 2013) } \\
\text { - Absolute welfare plays a greater role } \\
\text { (Kilduff et al., 2010; Kilduff et al., } \\
\text { 2012); higher tolerance for material } \\
\text { welfare differences (e.g. Henrich et al., } \\
\text { 2006; Irwin and Horne, 2013) } \\
\text { - Individual learning is predominant } \\
\text { - Independent tasks (Halevy et al., 2012) } \\
\text { such as wheat production (Luhrmann } \\
\text { (2014) } \\
\text { - Less efficient at handling public goods } \\
\text { - Negative subsidiarity concept (Watrin, } \\
\text { 2003); preference for peer punishment }\end{array}$ & $\begin{array}{l}\text { - Relative welfare plays a greater role } \\
\text { (Kilduff et al., 2010; Kilduff et al., } \\
\text { 2012); lower tolerance for material } \\
\text { welfare differences (e.g. Henrich et al., } \\
\text { 2006; Irwin and Horne, 2013) } \\
\text { - Rather other-regarding (Gintis, 2013) } \\
\text { - We-mode predominant (Tuomela, 2013) } \\
\text { - Conformist learning is predominant } \\
\text { - Higher social conformity (Bond and } \\
\text { Smith, 1996) } \\
\text { - Interdependent tasks such as rice } \\
\text { production (Luhrmann (2014) } \\
\text { - More efficient at handling public goods } \\
\text { - Positive subsidiarity concept (Watrin, } \\
\text { 2003); preference for institutional } \\
\text { punishment } \\
\text { - Tend to create public goods emanating } \\
\text { from socio-political ideologies } \\
\text { - Might have a higher present or historical } \\
\text { exposure to political or pathogen threat } \\
\text { (Fincher et al., 2008; Cashdan and } \\
\text { Steele, 2013) } \\
\text { - Tendency to Groupthink (Janis, 2008) }\end{array}$ \\
\hline
\end{tabular}

Figure 3. Characteristics of individualistic and collectivistic societies.

Further, individualistic societies are different from collectivistic ones. In Figure 3, I have listed a couple of characteristics of individualistic and collectivistic societies. 
Individualism or collectivism in societies can be influenced by the predominant production. Wheat farming people, for instance, have shown higher individualism, while rice farming people are more likely to be collectivists (Luhrmann, 2014). The reason for this is that different levels of cooperation are required depending on which types of products a society produces. Collectivistic societies are more efficient at handling public goods, and they have greater other-regarding attitudes and we-mode thinking. However, in my opinion, collectivistic societies also create public goods since their utility functions are more collective than those in individualistic societies. There, socio-political ideologies draw the collective attention to aspects of joined importance and collective enjoyment. To satisfy the desire of collective enjoyment, institutional $r \& p$ and coordination are necessary. By contrast, in individualistic societies, enjoyment is rather private, and coordination is more in the hands of individuals. Leaving the ontological and methodological dimensions aside and focusing on welfare theory, the common welfare theoretic denominator of collectivism and individualism can be found in the position adopted by Francis Hutcheson. He coined a statement which has ever since been attributed to utilitarianism: 'The greatest happiness [number of good] for the greatest number [of people]' (Hutcheson, 1729). Individualists consider utility to be primarily an individual joy. Hence, they focus on the 'greatest number of goods'. By contrast, collectivists rather focus on the latter, providing happiness or goods 'to the greatest number [of people]'. Consequently, collectivists pay more attention to public goods, as the non-rivalry of these goods makes it possible to satisfy more people with the same number of goods.

To cope with defection, collectivistic societies prefer institutional responses while individualistic societies favor peer punishment setups. These characteristics make collectivistic societies more hierarchical than individualistic ones. The readiness to escalate public goods problems creates stiffer hierarchies, while a preference for peer punishment keeps them flat. So, individualistic societies prefer to resolve public goods questions on their own, by peer punishment. Divergences in these preferences cause countries to react differently in certain situations. I will come back to this aspect in the next section. Further, some individuals are driven by absolute and independent motivations, while others are more guided by the relative welfare level or social rank of others (Kilduff et al., 2010; Kilduff et al., 2012) in a society. The latter results in an individual being ready to sacrifice part of his absolute welfare to improve his relative welfare level or social rank position (the de Tocqueville example), or to embrace greater conformity (e.g. Henrich et al., 2006; Irwin and Horne, 2013). All these characteristics lead to differences in punishment costs, punishment activity, and the appearance of anti-social punishment (Herrmann et al., 2008; Gächter and Herrmann, 2009; Bryson et al., 2012) in societies.

In behavioral studies, the participants are often chosen from democratic and affluent places (Sylwester et al., 2013) or so-called WEIRD societies ${ }^{3}$. It would be interesting

\footnotetext{
${ }^{3}$ Henrich et al. (2010). WEIRD stands for western, educated, industrialized, rich, and democratic.
} 
to see the results of certain studies when using people from regions of warfare or dysfunctional states typified by high corruption. Thus, public goods experiments could be used to analyze the extent to which post-violence or dysfunctional societies have "normalized" by establishing pro-social behavior patterns at a peer level. If the analyzed people have similar basic preferences, social comparisons will be possible without major obstacles. If the articulated preferences are diverse, they might be based on the same underlying basic needs. People might express identical needs in different ways. Further, they could have diverging basic needs which, however, all depend on the same resources (e.g. money or natural resources) and individual freedom to realize them. So, to make comparisons between societies - despite these differences - we must use characteristics which are sufficiently universal.

\subsection{Considerations on the subsidiarity principal}

The subsidiarity principle plays an important role in the shape of social hierarchies. In pro-social societies, social hierarchies emerge when individuals escalate public goods problems to higher levels. Here, I discuss different socio-political ideologies which influence the individual's escalation decision, and thus the emergence of hierarchical orders. The political theory about the subsidiarity principle does not pay much attention to the possibility of usurping power following from different ideologies (Watrin, 2003; Føllesdal, 2014; Delsol, 2015). However, in my opinion, these differences give societies a different shape and determine their predisposition to drift into authoritarianism. Vertical task allocation and a bottom-up perspective are an eminent characteristic of pro-social hierarchies. By contrast, power sharing and a topdown perspective are inherent in anti-social hierarchies. Both aspects can be found in the discussion about subsidiary principles. However, literature talks rather randomly about the task or power allocation (Føllesdal, 1998 passim). Normally, the assignment of tasks and responsibilities goes hand-in-hand with the corresponding empowerment. However, while the escalation starts with consensus about the attributed task in prosocial hierarchies, power sharing is at the center of thinking in anti-social hierarchies.

Part of the subsidiarity theory is the principle of proportionality. This describes the extent to which a higher unit should support a lower unit und thereby interfere with its affairs. The provided support should be in proportion to the needed help. This (apparent) need for help is lower when applying a bottom-up rather than a top-down perspective. Martin (2010) tested that question by interviewing members of the European, Federal German and Bavarian parliaments. He found that the members of lower parliaments are more restrictive in terms of the need for help. The principle of proportionality also means that the interventions must be balanced between public interests and the individual's right for autonomy. Looking at the etymology of subsidiarity, the term comes from the Latin word subsidium (help) ${ }^{4}$, which means that

\footnotetext{
${ }^{4}$ Endo (1992), referring to Jean-Marie Pontier "La subsidiarité en droit administrative" (1986).
} 
help should only be provided where the lower unit is not able to fulfill a task using its own means. The term was originally used for military reserve resources to be allocated where existing local resources were not enough. So, the resource allocation concept of subsidium implied a top-down perspective. By contrast, calling for help stems from a bottom-up perspective.

Further, the underlying ideology influences the outcome, too. A collectivistic ideology recommends more interventions than an individualistic one, as it applies a top-down perspective. It puts the definition of when support should and should not be provided - I call this the subsidiarity threshold - in the hands of the superiors. This top-down perspective is predominant throughout history. Jean Pierre Proudhon ${ }^{5}$ wrote that 'everything that can be executed by the individual to submit oneself to the law would be left to the individuals'. This perspective means that somebody from a higher rank decides what to 'leave' to the lower ranked individuals. The subsidiary thresholds definition in Proudhon's subsidiarity concept, as well as the task and power allocation, are applied top-down. Pope Leo XIII, in his 1891 Rerum Novarum - like Pope Pius XI in his Quadragessimo Anno 40 years later - unsurprisingly approached the subsidiarity principle from a top-down perspective. All this implies the assumption that there is an omniscient social planner who decides what autonomy can be conceded to the people.

Thomas Hobbes applied both perspectives in his Leviathan. He wrote that '... a multitude of men do agree, ... that to whatsoever man... shall be given ... the right to present the person of them all...' (Hobbes, 1985) (bottom-up). But once the individuals agreed on this, they '... are subjects to a monarch, [and] cannot without his leave cast off monarchy...' (ibid.) (top-down). By contrast, liberal testimonies clearly start from the individuals' perspective. This was the case in the $18^{\text {th }}$ century American preconstitutional debate. Both federalists (e.g. Kesler, 2003: No.51; a Publius article for a moderate position) and anti-federalists (e.g. Ketchman, 2003: 292f.; a Brutus article for a radical position) took a bottom-up view and critical position on the escalation of power. This perspective perdured, as de Tocqueville (2011: 148) wrote fifty years later in the 1830s: 'The citizen of the United States is taught from his earliest infancy to rely upon his own exertions... and [he] only claims [the authority's] assistance when he cannot do without it'. Bottom-up and top-down perspectives can also be found in the contemporary discussion about civil participation in democracies (e.g. Navia, 2008; Smith, 2009) or authoritarian regimes (e.g. McNulty, 2012; Owen, 2020). While there is a top-down, bottom-up combination in democracies, authoritarian regimes are purely top-down. The top-down, bottom-up distinction corresponds to the exogenous versus endogenous institution choice discussion in behavioral science (e.g. Botelho et al., 2019; Dannenberg and Gallier, 2019; Marcin et al., 2019). Here, the endogenously

\footnotetext{
${ }^{5}$ Endo (1992), referring to Pierre-Joseph Proudhon's "De la capacité politique des classes ouvrières"(1865). French original: 'Tous ce que peut exécuter l'individu, en se soumettant à la loi de justice, serait donc laissé à l'individualité.'

${ }^{6}$ Both can be found in Endo (1992).
} 
(bottom-up) built institutions tend to be more efficient (ibid.). This discussion about bottom-up or top-down perspectives leads to a number of important politicaleconomical questions. Who has the sovereignty to define the subsidiary thresholds? They define whether a certain task and the related power are attributed to the next higher or the next lower level. Who has sovereignty over the threshold-influencing parameters like the ideological environment? The power for these steps is not necessarily in the hands of the same people. Power lies not only with the one who possesses power within given subsidiary structures, but also with the one who defines the structures following on from the subsidiary thresholds.

To show some characteristics of the subsidiarity discussion, I have chosen a politological classification which is illustrated in Figure 4. The model is not limited to the molding of political institutions. It comprises the subsidiarity decisions of all individuals in their everyday lives - including outside the political institutions. Figure 4 distinguishes between three major streams: liberalism, federalism and statism. Liberalism focuses on the individual, the citizen, and begins its reasoning from there. By contrast, I label all ideologies which start their reasoning with the state, the political order, and a collectivistic view of society as statism. Statism theories range from communist and socialist to conservative types. In each of them, the state plays a central role in the planning and realization of the respective ideology.

I further introduce the concept of efficient statism, which is the conviction that by driving the statism idea "to perfection", society will reach ever better social welfare levels. These societies chose to trade individual freedom for the desired higher socioeconomic efficiency (Toelstede, 2019/2 and 2020/1). Efficient statism is not the same as political paternalism. It stems from a subsidiary principal in which society agrees that the state intervenes in many daily socio-economic processes to improve its socioeconomic efficiency. The citizens, in turn, also play a role by agreeing to higher levels of conformity and accepting the public goods which the government offers (Toelstede, 2019/2: 19). By contrast, paternalism stems from a caretaker view which implicitly assumes that citizens require assistance and guidance in their everyday activities (e.g. Sunstein (2014) for well-intended soft paternalism and Chaloemtiarana (2007) for despotic paternalism, to show the sociality range of paternalism).

Although the appearance of both can be very similar, the underlying concepts and viewpoints are different. In efficient statism, society progressively includes the state in the subsidiarity concept and attributes it an active coordination role. Society accepts long principal-agent chains, and is ready to give up individual freedom for the sake of socio-economic efficiency. In paternalism, political agents believe that they have a caretaker duty vis-à-vis society. At the same time, these agents consider that the members of this society require their assistance and guidance, and therefore do no not regard them as sovereign principals. Efficient statism can fail if the principal-agent chains break. Will the political agents in such a situation always be 'principled agents' (Besley, 2006; Toelstede, 2020/1: 11) or will they rather become "principaled agents", meaning that the political agents turn into their own principals? Driving the 
socio-economic reasoning of efficient statism to its extremes can cause democratic descent. It might end in 'authoritarian welfare states' (Forrat, 2012) when social welfare is more important, or 'growth-friendly dictatorships' (De Luca et al., 2015) when economic welfare is predominant.

Between statism and liberalism lies federalism. Federalists aim for an optimal subsidiary task allocation, even though the optimality definition is not always entirely clear and unanimous. Hierarchies are not in all cases the most efficient organizational structure (Halevy et al., 2012; Pieterse et al., 2019; Reit and Halevy, 2020); the optimal structure depends on the kind of task. If the tasks are fairly independent from each other, it is better not to use vertical structures. If the tasks are interdependent, hierarchy enhances group performance (ibid.). Following the idea of federalism, in order to shift a task (i) from one level (j) to the next higher level $(j+1)$, the marginal costs of managing that task on level $\mathrm{j}$ must be higher than handling the task on level $\mathrm{j}+1\left(\mathrm{C}^{\prime}{ }_{\mathrm{ij}}\right.$ $\left.>\mathrm{C}^{\prime}{ }_{\mathrm{ij}+1}\right)$. This model - and the federalists themselves - implicitly call for the additional power asymmetry which would result from a vertical escalation and how it can be balanced out. Applying that formula to all tasks and levels would result in a natural coordination hierarchy. However, this social engineering process can be misused to justify one or other of the ideological preferences, which - in turn - influence all $\mathrm{C}{ }_{\mathrm{ij}}$.

Figure 4 describes the three concepts. The most important aspect of this distinction is that applying one concept or the other has a huge impact on the shape of the social hierarchy and the resulting power asymmetries. Subsidiary decisions in a liberal setup are, in general, characterized by more individualistic viewpoints on society, a bottomup perspective, and a negative freedom interpretation which means freedom from government action. Liberalism results in flat social hierarchies. Statism viewpoints, in turn, are more collectivistic, top-down, and centralized, and have a positive freedom definition which means freedom through government action. The later can lead to Nell-Breuning's 'subsidiarium officium' (Watrin, 2003), which is a normative postulate that wherever politicians see a possibility of providing additional public goods to the population, politicians should feel obliged to do so. This causes a hierarchy-enhancing dynamic, as there are no limits to finding or "inventing" new public goods. The results are steeper social hierarchies.

In my opinion, the natural state of an individual is to manage his affairs himself and not to be managed by somebody else. Or, as Jean-Jacques Rousseau phrased it: ' $A$ society which governs itself always well does not need to be governed'. Therefore, when thinking about subsidiarity questions, the point of departure should be - but very often is not - the individual and the bottom-up perspective. Departing from that point, it is the individuals who compose the social structure, meaning institutions follow from [the citizens'] intuitions' (Cushman, 2015 paraphrased).

\footnotetext{
${ }^{7}$ Rousseau (1766) book $3 \mathrm{ch}$. 4. French original: “Un peuple qui gouvernerait toujours bien n'aurait pas besoin d'être gouverné."
} 


\begin{tabular}{|c|c|c|c|}
\hline $\begin{array}{l}\text { Politological } \\
\text { classification }\end{array}$ & Liberalism & Federalism & Statism \\
\hline $\begin{array}{l}\text { Hierarchical } \\
\text { perspective }\end{array}$ & \multicolumn{3}{|l|}{ Bottom-up } \\
\hline $\begin{array}{l}\text { Socio-ontological } \\
\text { view and society's } \\
\text { self-understanding }\end{array}$ & \multicolumn{3}{|l|}{ Individualistic } \\
\hline Sovereignty over the & \multirow{2}{*}{\multicolumn{3}{|c|}{$\begin{array}{r}\text { In the hands of leaders or individuals } \\
\text { close to them }\end{array}$}} \\
\hline & & & \\
\hline $\begin{array}{l}\text { Subsidiarity } \\
\text { definition }^{8}\end{array}$ & \multicolumn{3}{|l|}{ Negative } \\
\hline Freedom definition ${ }^{9}$ & \multirow{2}{*}{\multicolumn{3}{|c|}{ Positive }} \\
\hline & & & \\
\hline $\begin{array}{l}\text { Social, political, and } \\
\text { economic planning }\end{array}$ & \multicolumn{3}{|c|}{ Preferably decentral } \\
\hline $\begin{array}{l}\text { Underlying } \\
\text { thoughts and } \\
\text { convictions }\end{array}$ & $\begin{array}{l}\text { Individual } \\
\text { liberty } \\
\text { Freedom from } \\
\text { heteronomy }\end{array}$ & $\begin{array}{l}\text { Balancing out } \\
\text { socio-economic } \\
\text { efficiency, } \\
\text { individual } \\
\text { interests, and } \\
\text { power } \\
\text { asymmetries }\end{array}$ & $\begin{array}{r}\text { Social conformity } \\
\text { (behavior or } \\
\text { welfare levels) } \\
\text { Propensity to } \\
\text { escalate } \\
\text { responsibilities } \\
\text { Cost-sharing } \\
\text { motive } \\
\text { Power and social } \\
\text { planning affinity }\end{array}$ \\
\hline
\end{tabular}

Figure 4. Subsidiarity views of different socio-political ideologies.

\footnotetext{
${ }^{8}$ Watrin (2003) also mentions Oswald von Nell-Breuning, who is one of the strongest defenders of a positive subsidiarity definition. He quotes him freely: "subsidiarity is not a principle, but a subsidiarium officium, a duty of the community [the state] to help its members in the fullest sense of the word. Namely to give them the opportunity to develop themselves to their fullest as people." (p. 7.) Watrin admits that, for this purpose, taxes could be enforced.

${ }^{9}$ Berlin (1969). Berlin defines the individual's desire to be his own master and not to be interfered by anybody else as positive freedom (bottom-up view in my model). On the contrary, he defines the area of freedom which could be left [by a social planner] to the individual as negative freedom (top-down view in my model).
} 


\section{Path dependence and social hierarchies}

Article 2 describes the emergence of path dependence in hierarchical and nonhierarchical societies. I use the path dependence model to describe certain dynamics within the Structure-Behavior Diagram. To complement the thoughts presented in the article, I describe in the following some constellations of evaluation and political decision-making under uncertainty. These constellations entail path-creating mechanisms such as sequence, power, stereotypy, or conformity. This shows that path dependences are a very normal part of our daily life and decision-making under uncertainty.

\subsection{Path dependence degrees and foreseeability}

Path dependence emerges slowly with small and inconspicuous steps, which means that its foreseeability emerges gradually. In Figure 5, I illustrate constellations of political decision-making with path-creating consequences under uncertainty. I discuss the degree of path dependence emerging from wrong decisions. Wrong decisions can be due to two main reasons. First, they may be due to bounded rationality, meaning that the individuals, a priori, did not know or could not have known about the suboptimality of the decision. Second, despite the good availability of information, asymmetries in information and decision power can cause a society to choose a path which is good for some and bad for others. To discuss these questions, I use Liebowitz and Margolis' (1995) model, which distinguishes between three degrees of path dependence. Degree 1 describes the simple assertion that the inter-temporal relationship exits' (ibid. p. 210), but this type of path dependence will not result 'in any inefficiency' (ibid. p. 210). This is the case when many paths exist where all are optimal, and we just need to choose one of them. Degree 2 occurs when decisions are taken with imperfect information and 'the sequent events reveal to be inferior to some alternative' (ibid. p. 211). Degree 3 defines the situation where the chosen alternatives are 'ex-ante path-inefficient' (ibid. p. 211).

Liebowitz and Margolis also thought about the question of why actions should be taken which foreseeably lead into a suboptimal path. However, their considerations focused on decisions about technologies with a well-reflected decision process. Hence, they argued that the probability of degree 3 path dependence and its consequences would be small (ibid. pp. 216-217). Further, they (implicitly) abstracted from any politicaleconomic aspects. Nevertheless, for the topic of this thesis, political economy is very important and requires more attention. A closer look at the nuances between degree 2 and degree 3 paths is necessary. So, I introduce two major areas to describe the space between degree 2 and degree 3. The different phenomena, which will be described below, will help to explain why wrong decisions and their path-creating consequences are a normal part of societies. 


\section{Foreseeability}

\section{Path}

dependence

Impossible to know for anyone

Pure degree 2 path dependence

Bounded rationality: The people fail to see the risk of an inefficient path because of... (A)

- the possible effects are known, but the timing is unknown

- overconfidence (Zacharakis and Shepherd, 2001; Fast et al., 2012)

- conjunction fallacy (Tversky and Kahneman, 1983; Kahneman, 2011)

- base rate neglect ${ }^{10}$ or correlation neglect (Enke and Zimermann, 2013)

- alternatives and risks being erroneously evaluated

- self-righteousness (Krebs and Denton, 2005)

- $\quad$ self-deception (Von Hippel and Trivers, 2011)

- conformity (Asch, 1955) and cascades (Sunstein, 2019 for an overview)

- willful ignorance (Lynch, 2016)

- decision avoidance due to fear (Anderson, 2003)

- personality traits, e.g. psychopathy (Vize et al., 2018)

Political economy: Some individuals know, but... (B)

- hold back relevant information

- frame the problem and the decisions (Tversky and Kahneman, 1981) in a specific way to influence the outcome

- deliberately cheat the rest

- do not intervene; strategic delay (Chamley and Gale, 1994)

- have no voice

- fear being punished when the object against a common trend

- show willful ignorance in agency (Grossman and Van der Weele, 2017)

- have personality traits like Machiavellianism and narcissism (Vize et al., 2018)

Everyone knows, but deliberately ignores it.

Pure degree 3 path dependence

Figure 5. The nuances between degree 2 and degree 3 path dependence.

Arthur defined the 'small historical events' as those 'events or conditions that are outside the ex-ante knowledge of the observer' (Arthur, 1989: 118), which corresponds to the pure degree 2 definition in the Liebowitz-Margolis model. Liebowitz and Margolis use a less restrictive definition, saying that 'agents are making seemingly minor decisions that have major consequences' (Liebowitz and Margolis, 1995: 212).

\footnotetext{
${ }^{10}$ Tversky and Kahneman (1981), Kahneman (2011). Further, Hinsz et al. (2008) discovered that groups can show
} higher base rate neglect than individuals. 
This allows them to assume that actors sometimes underestimate or ignore the possible consequences of their decisions. The definition of what persons could have known and done before reaching a critical conjuncture or lock-in is quite difficult. This becomes even more difficult the more we dig into earlier and smaller events when explaining path dependence. Hence, we should be careful to judge from the position of a 'hypothetical omniscient observer' (Liebowitz and Margolis 1995, p. 216).

Path dependence theory usually assumes anonymous market mechanisms and decentralized decision-making (Arthur, 1989 and 1994 passim; David, 1985: 336). On the other hand, organizational path dependence theory considers hierarchies with centralized decision-making (Petermann, 2010: 118). Decision-making in vertical social structures is a combination of central and decentral decisions. It is an asymmetric group decision between the leader(s) and the respective selectorate (De Mesquita et al., 2002). This means that a decision is collectively taken by the leader, who implicitly takes his followers' positions into account as the followers are his selectorate. We can assume that each selectorate, in turn, has its own selectorate, which would lead to a cascadic model - I call it a "selectorate cascade". Even if the selectorate is not visibly involved in the leader's decisions, the latter's actions influence the relationship with the former and the acceptance or non-acceptance of the same. Hence, the leader anticipates the selectorate's reaction.

In an analogy to the Liebowitz-Margolis distinction, Figure 5 illustrates a selection of nuances between degree 2 and degree 3 path dependence. The cases of pure degree 2 or degree 3 are the cornerstones of the model. For instance, degree 2 could be a sudden meteorite impact. ${ }^{11}$ The space between degree 2 and degree 3 path dependence in Figure 5 has a bounded rationality and a political-economic dimension. The first dimension describes situations where "all are equally uninformed and/or irrational". The second dimension describes a situation where "some people know or can decide, but others do not know or cannot decide". In political reality, numerous nuances and combinations between these two dimensions are possible. See also Schippers et al. (2014) for a similar categorization. All of them can cause path-creating mechanisms (Toelstede, 2019/2).

Milan Svolik (2012) discussed the predictability of the Jasmine Revolution in Tunisia and the break-down of authoritarian regimes in parts of the Arab world. His conclusion can be summarized as an erroneous evaluation of the likelihood and the consequences of a possible popular uprising. Political history is full of these 'black swans' (Taleb, 2007). Retrospective analyses of historic events can bring interesting nuances to light, in view of what certain political actors knew or could have known. Christopher Clark (2012) did this in his book about the outbreak of World War I. He carefully analyzed how political actors were struggling to recognize - on individual and collective levels - the consequences of the saber-rattling diplomacy of the time. His analysis showed

\footnotetext{
${ }^{11}$ However, this example could lead to the question of whether it is possible to classify an incident as unforeseeable if its mere (a priori) mention expresses an awareness of its possible occurrence.
} 
that some actors on both sides were subject to erroneous evaluation, overconfidence, or self-deception. Others foresaw the negative consequences of an armed conflict but feared being punished if they objected. Finally, the degree 3 case might only work in the short-term and in conjunction with collective stereotypy, increasing the myopia of a society or psychopathic individuals. Otherwise, the society should see the suboptimal path and it is unlikely that the people would not try to avoid it. 


\subsection{Bounded rationality}

Area A in Figure 5 focuses on the bounded rationality of individuals and groups. It clusters those situations where a society could be aware of a suboptimal path but, for various reasons, nobody sees it. The society's evaluative capabilities can be limited or biased (i.e. ideology, stereotypy, conformity). In area A, all society members are equally (un-)aware, (un-)informed, able to evaluate, and biased or irrational. Here, the whole society somehow tries to foresee the future in the best possible way despite its limitations. Consequently, the society takes consensual decisions which are a priori optimal but a posteriori suboptimal. I briefly discuss some of the scenarios of bounded rationality and political economy. However, a clear separation of the two is not always possible.

An overconfidence bias occurs when leaders are overconfident and/or their followers have too much confidence in the leaders. This can happen in conjunction with a 'social myth' (George Sorel cited by Hayek, 1944/2007: 174), which leaders use to convince followers of their ambitious and overstretched targets. Overconfidence can follow from 'opinion convergence' (Lorenz et al., 2011), a kind of conformity which is pathcreating (Toelstede, 2019/2). Leaders will have difficulties stepping away from their original positions at a later stage without being deposed by their followers. So, before this divergence comes to light, the leaders need to secure their position with a structural lock-in. I will come back to this later. Individual and collective overconfidence is context-dependent (e.g. Muthukrishna et al., 2014).

Another form of bounded rationality is self-image protecting self-deception (Cowen, 2005), where individuals discard information that is relevant for making decisions, but which harms their self-image. Bénabou (2012) presented a model of collective delusion which starts at individual level and spreads to become collective. $\mathrm{He}$ distinguished between hierarchical societies and non-hierarchical ones. In the former, the real and the delusive information cascades from the top to the bottom. In horizontal societies, the delusions and realities spread randomly from peer to peer. Further, Bénabou proposed a mechanism called 'mutually assured delusion', which could create different 'social cognitions' (ibid. p. 2) of the same social reality. In other words, the members of a group create - by mutual assurance of their individual delusions - a collective and distorted belief about a given fact.

To begin with, this process might be free of constraints; the individuals experience a cognitive ease when their individual delusions are confirmed by others. Later, when the distortive characteristic of the collective perception becomes obvious, the individuals might be prevented from revising their view by group constraints. This is because the collective but delusive view has gained public good character within this group. Abolishing this illusive viewpoint means damaging the public good of the group, which can be subject to punishment. This mechanism mainly occurs between individuals of a subgroup with good internal trust levels, cheap communication, and 
shared values. This could be between the members of a ruling coalition. The individuals will avoid jeopardizing these public goods. Therefore, mutually assured delusions can foster parochialism, in-group favoritism, and stereotypy. Mutually assured delusions obscure the existence of better paths and, thus, bias or even inhibit an objective evaluation of possible alternative paths. They could lie like a veil over the set of alternatives and help to defend the privileges of certain society members, which gives them a political-economic dimension.

Bounded rationality has also been investigated in investors' behavior in capital markets (e.g. Hirshleifer et al., 2003; Hirshleifer, 2015). Even though this is not the same environment as vertical social structures, certain behavioral patterns such as biased perception, extrapolative expectations, herding (Cipriani and Guarino, 2005), cascading (Alevy et al., 2007), thought contagion (Hirshleifer and Teoh, 2009), or 'this time is different' beliefs (Gennaioli et al., 2015) can also be applied in social hierarchies. The advantage of financial markets and investors' behavior is that it is easier to examine than behaviors in political systems. The availability and quality of data are better. The setup of these models and their findings are a good baseline for behavior analyses in political systems. To conclude, this enumeration of realizations of bounded rationality is not exhaustive, and the presented discussion is superficial. My aim was to give an overview of its variety. This is an interesting area for further research to be embedded into the path dependence considerations and the StructureBehavior Diagram.

\subsection{Political-economic aspects}

The political-economic aspects in Figure 5 show situations where only some people know about the suboptimality and use this advantage to improve their position within the society. This area therefore deals with tactical questions. In the following, I present a selection of possible situations. Let us assume that some well-informed and influential group members foresee the sub-optimality of an emerging path - I call them "foresighted individuals" or a "foresighted group". However, despite their knowledge about the sub-optimality of the emerging path, they do not act against this trend. One political-economic reason consists in different pay-off functions between higher ranked and foresighted individuals and the lower ones. Further, there is a possibility of being punished or losing privileges when sharing the knowledge about an emerging sub-optimal path. This goes along with certain society-internal asymmetries, which I briefly mention and discuss their respective occurrences in networks, coordination and dominance hierarchies. For a definition of these structures, see Toelstede (2020/1). 
The asymmetries can be related to:

- relevant information

- foresightedness (=ability to anticipate future scenarios)/time preference

- evaluative capability

- political voice/decision power (=power asymmetries)

- pay-off functions

In networks, all these aspects are mutual and equally distributed. There could be different pay-off functions, but they are balanced out by the absence of power asymmetries. Therefore, we will hardly observe the emergence of any politicaleconomy-driven path dependence in networks. In coordination hierarchies, these asymmetries are distributed according to the rank order of the individuals within the hierarchy. Everyone's rank in a coordination hierarchy corresponds to his foresightedness and evaluative capacities, which result from the individual's human capital. Power asymmetries are also in line with this. Importantly, the foresighted individuals do not abuse these advantages in relation to the lower ranked, as rank, human capital, and power asymmetries are in balance. In a dominance hierarchy, the information and power asymmetries are abused by the higher ranked to oppress the lower ranked. Further, the hierarchical structures of a dominance hierarchy are in a vertical structural lock-in - meaning that there is no vertical fluidity of persons as in coordination hierarchies. Structural lock-ins sustain the hierarchical corset even though the different asymmetries cause many tensions within the society. In the case of a foresighted group, the privileged information is a group-internal public good and sharing it with the rest of the society would be defection. This defection could be punished by the group members. Foresighted groups can be found in coordination hierarchies and dominance hierarchies. In $\mathrm{CHs}$, the information slowly trickles down to the lower parts of the society, while in $\mathrm{DHs}$ there are systematic burdens to prevent this trickle down. Especially in stratified societies, each social layer is more foresighted than the next lower layer. These societies can be modelled as a multitude of small cooperations - a continuum of small groups in the vertical social space, sealed off one from each other. They are marked by a continuously descending foresightedness and shared information.

Figure 6 describes a situation where the higher ranked and foresighted individuals (leaders) deceive the lower individuals (followers). The original welfare distribution is given by $\mathrm{t}_{0}$, with the tolerance vector between $T_{A}$ and $T_{B}$. The tolerance vector describes a welfare development range for the followers (A) and their leaders (B). In this case, the leaders play with an illusionary welfare development for the followers. The leaders drive the society onto path II, which initially offers benefits for the society. They lure the society with a good but illusive welfare perspective, $t_{3}$ (illusive). However, in the long run, the path provides a welfare shift from the society to the leaders. To get away with this deceit, the leaders need to ensure that the hierarchical structures have reached a vertical structural lock-in before $\mathrm{t}_{1}$, or by $\mathrm{t}_{2}$ at the latest. This vertical structural lock-in traps the society in the hierarchical order and lowers the chances of 
any uprising. Finally, the society ends up in a welfare distribution of $t_{3}$ (actual) and not in the expected $t_{3}$ (illusive). The sequence of this process is: deceit, decision, emergence of a suboptimal path, vertical structural lock-in, welfare redistribution in favor of the leaders, realization of the illusion by the lower ones. The necessary strengths of the vertical structural lock-in increase with the intended level of welfare distortion. The abuse of different levels of foresightedness in a society to drive it into a path dependence is an important political scenario in the analysis of transitions between democracies and authoritarianism.

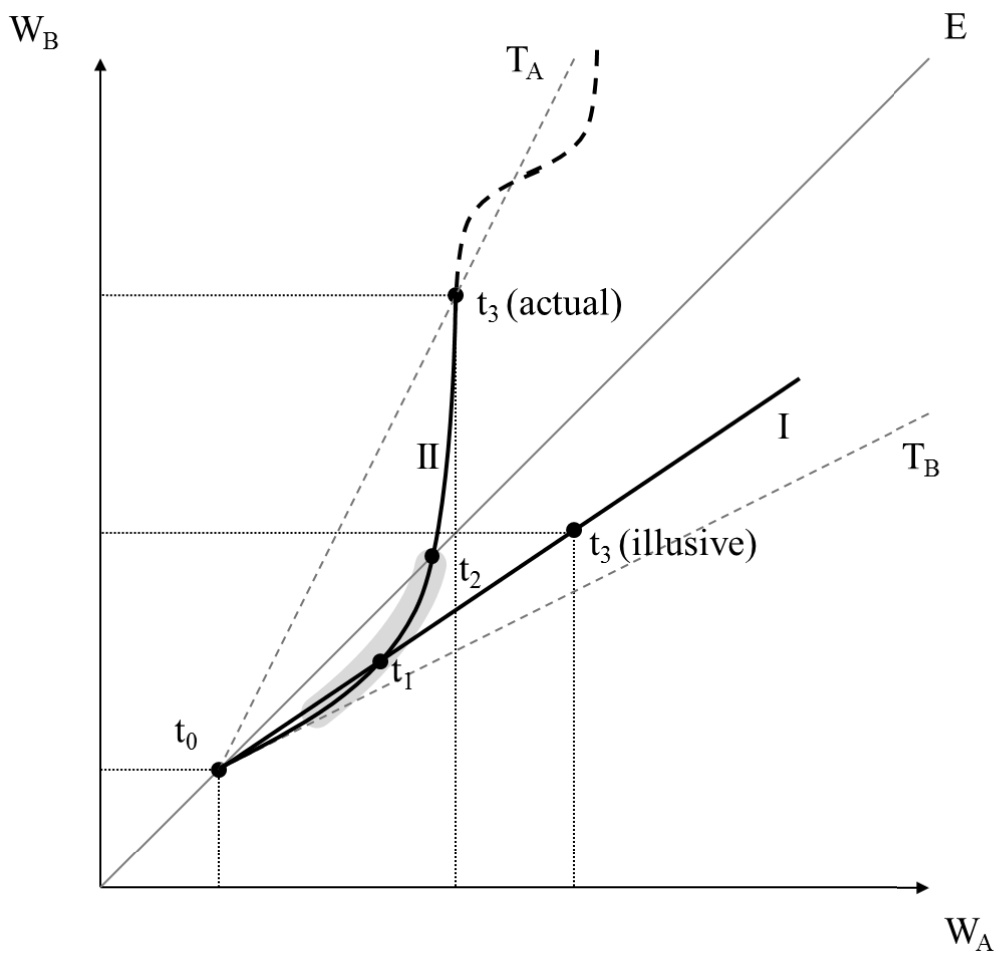

Figure 6. Welfare distribution before and after reaching a structural lock-in.

Another behavioral option is not to intervene (just let it run). The foresighted individuals might fear being punished when they intervene, or might consider the process to be irreversible in any case. So, in addition to the situation of being exposed to social constraints, political actors might assume that the society is locked-in on a path (a process lock-in). In this case, the actors' non-intervention can also be a covered repositioning. This means that they expect a change or breakdown in the current social structures and prepare themselves for the time afterwards. Chamley and Gale (1994) described the behavior of 'strategic delay' in a study of investors in capital markets. 
The decisions in their model were assumed to be irreversible, which gave them a sequential path-creating character (Toelstede, 2020/1). The actors improved their position by deliberately delaying their actions. Later, Dasgupta (2007) developed a game-theoretical model which describes how the 'calculus of strategic delay' of decisions influences an individual's pay-off. The model shows a tradeoff between early and risky action or delayed action with more private information and, hence, lower risk. The environmental assumptions of the Dasgupta model do not consider vertical social structures, information, or power asymmetries. However, this could be interesting for future research. Dasgupta's results show that delaying actions is rational for individuals and groups.

Lastly, there are personality traits such as Machiavellianism, narcissism, and psychopathy (Vize et al., 2018), which can lead to suboptimal decisions. Machiavellianism relates to leaders who maliciously abuse the power given to them. This can be supported by the authoritarian character of their followers (Harms et al., 2018). Together with narcissism (Watts et al., 2013), it can cause politico-economic decision patterns which are suboptimal for societies. Psychopaths, despite only making up about $1 \%$ of a population (Boddy, 2005), are associated with cognitive intelligence (ibid.) and higher rationality in social dilemmas (Osumi and Ohira, 2010), which could promote their rise through social ranks. This means that, in hierarchical societies, these individuals can obtain powerful positions. By contrast, in horizontal societies, these individuals are more randomly distributed within the society and the power given to them is countervailed by their peers (Seabright in Sterelny et al., 2013: 109). Narcissism and psychopathy can be positively correlated to power distance (Robertson et al., 2016). Personality traits have positive and negative sides (e.g. Judge et al., 2009; Watts et al., 2013; Smith et al., 2018). They can show different decision patterns in organizations (Figure 5) which result in different path-creating mechanisms (e.g. sequence, power, stereotypy). More analyses might help to better describe the influence of different forms of these personality traits on social path creation within the dependency of the respective environment. In particular, the characteristics and strengths of the principal-agent chains of these individuals with their environment might play an important role.

To summarize, there are several aspects which influence individual and collective decision-making, and which have a path-creating character. In most cases, societies autocorrect suboptimal paths over time (Toelstede, 2019/2). However, this enumeration shows, together with the path-creating mechanisms (ibid.), that suboptimality and path dependence are eminent aspects of societies and their democratic orders. Further research might give us even deeper insights into the presented topics. 


\title{
5. The articles and their role within this thesis
}

\author{
5.1. Article 1: Social Hierarchies in Democracies and \\ Authoritarianism: The Balance between Power \\ Asymmetries and Principal-Agent Chains
}

\subsubsection{Summary of the article}

Social hierarchies exist in democracies as well as in authoritarian societies. However, their nature is different. Democratic hierarchies are built bottom-up through election, while autocratic hierarchies are built top-down through domination. Both, however, have power asymmetries between the weaker citizens and the stronger politicians, which are amplified the stronger the hierarchies are. This manuscript introduces a model which combines pro-/anti-social behavior with different degrees of hierarchies. It is argued that this model has the power to categorize countries according to these criteria, and indicates when and how societies move between democracy and authoritarianism. Importantly, I illustrate that the balance between power asymmetries and principal-agent chains is key for understanding when and why democracies sometimes transcend into authoritarianism.

\subsubsection{Discussion}

This article introduces the Structure-Behavior Diagram, which represents the basic model of my thesis. It frames the political space in which all other considerations and observations take place. I define four society types following on from the combination of the two criteria of sociality and verticality. I describe the characteristics according to which countries are to be "located" in one of the areas of this political space. I show that for pro-social societies, the escalation of public goods coordination from peer to institutional punishment correlates to the pro-sociality of the political system. In other words, the citizens escalate political power to the government in dependency of the quality of governance. The positively inclined line results from the correlation between pro-sociality and political task escalation (Toelstede, 2020/1 Figures 7 and 8). All EU and OECD (except Mexico) countries are around this line. This confirms the positive relationship between pro-sociality or 'effective democracies' (Inglehart and Welzel, 2005) and socio-economic welfare levels (e.g. Barro, 1996; De Haan and Sturm, 2003; Acemoglu et al., 2019; Colagrossi et al., 2020). The correlation between pro-sociality and political task escalation is similar to Besley and Persson's (2019) relationship between democratic values and acceptance of institutions. However, their correlation between 'cumulative democracy' and 'institutional support' produces different results. It implicitly assumes that the longer a society is democratic, the more democratic 
institutions should have been built up and the better they should be supported by the society. By contrast, my model asks for the actual pro-sociality (measured by 'personal freedom' (CATO, 2017 and 2018)) and not the historically acquainted one. This means that the two studies, despite positive correlations in both models, arrive at different results for certain countries (e.g. France).

At the end of the article, I indicate the existence of other patterns in this political space. There are burdens, which I call "thresholds", and dynamics which emerge when they are crossed. One of these could be the point of maximum anti-sociality of authoritarian regimes. This threshold should depend on the level of power asymmetries to protect the regime from civil uprising. Hence, it should be a vertical line inclined to the right and located in the DH area. This limit derives from the abovementioned tolerance limit. Another threshold is the point of authoritarian break-down - in other words, the point where authoritarian structures melt and crumble (when moving top-down) or crystallize and consolidate (when moving bottom-up). This threshold should be located between DH and SON. Lastly, I assume that the transition between pro- and anti-sociality is different at different power asymmetry levels. This is already an implicit part of some of my articles, but there is more to be explored as I indicate at the end of these publications. For example, the incentives for anti-social descent or the (anti-social) power to prevent the emergence of pro-social reward and punishment (Rand et al., 2010; Hauser et al., 2014). In horizontal societies, the possibly existing anti-social punishment has no power asymmetries in its favor to prevent the evolution of pro-sociality (see the example of Tunisia in Toelstede 2020/1).

\subsection{Article 2: How path-creating mechanisms and structural lock-ins make societies drift from democracy to authoritarianism}

\subsubsection{Summary of the article}

The question of how societies move between democracy and authoritarianism is of vital interest in science, as well as in the day-to-day political debate. This article contributes to this debate by exploring which mechanisms potentially encourage societies to move from democracy to authoritarianism. This article is based on the idea of traditional path dependence, tracing back to Arthur and the organizational path dependence theory of Sydow et al. (2009 and 2020). Building on these theories, I examine how so-called path-creating mechanisms can emerge and influence societies to move from democracy to authoritarianism. I develop two new concepts in this article. First, structural lock-in, which describes a society deprived of its capabilities to adapt to the continuously changing environment. Second, efficient statism, describing societies which strive for higher socio-economic efficiency by embracing strong governmental forms and high conformity levels. The empirical cases presented 
in this article show that the path-creating mechanisms and efficient statism are regularly observable in societies. Such mechanisms put democracy at risk.

\subsubsection{Discussion}

The underlying idea of introducing the path-dependence model into my model is that I presume that societies experience certain dynamics when moving within the political space, and especially between democracy and authoritarianism. Embedded in the Structure-Behavior Diagram, the path-dependence model enables us to explain these dynamics. I show that some of these path-creating mechanisms act differently depending on the strength of the social hierarchies.

Further, I present the term efficient statism, which describes a situation where societies willingly trade personal freedom for higher socio-economic efficiency. I show that societies which pursue this objective, consciously or unconsciously, reconcile themselves with certain path-creating mechanisms. Those societies have a collectivistic welfare viewpoint and apply a collective utility function. They prefer using public goods to satisfy this utility function. The unification of a multitude of individual utility functions into one collective function - despite being questionable from a theoretical perspective - requires, in the eyes of this ideology, conformity and stereotypy. These, in turn, have path-creating and freedom-limiting characteristics (Sunstein, 2019). These societies accept less individual freedom as well as higher power asymmetries between the citizens and their respective government. These limitations can, to a larger extent, also be observed in limited democracies and semiauthoritarian regimes. So, efficient statism, if driven too far, brings a risk in the form of overly strong power asymmetries, ideology, conformity, stereotypy, and a lack of pro-sociality. All this makes democratic societies more prone to drift into authoritarianism (DH).

I further show that striving for stability is treacherous, as it might create structural lock-ins and deprive societies of their 'dynamic capabilities' (Teece et al., 1997). I speculate that the desire for stability follows from fear associated with social change and the preference for safety and socio-economic security. The potential lock-ins and path dependences resulting from that view support a saying attributed to Benjamin Franklin, whereby preferring safety over freedom entails the risk of losing both. Figure 4 in this article (Toelstede, 2019/2: 7) illustrates a Nash equilibrium with equal payoffs (9/9). This illustration implicitly assumes that both players have the same power to choose one of the alternatives. This is the case in horizontal societies without power asymmetries. However, in hierarchical societies with power asymmetries, one player could have the power to exclude certain alternatives from the game. He would thereby obtain a better pay-off for himself (e.g. 10/5 if A has the power to exclude B's option III from the game and chooses alternative III for himself). So, the possible Nash 
equilibria without power asymmetries are different from those which are possible with power asymmetries.

\subsection{Article 3: Democracy Interrupted: The Anti-Social Side of Intensified Policing}

\subsubsection{Summary of the article}

In 2015 and 2016, France was hit by a number of severe terror attacks. Following these attacks, the country experienced increased xenophobia in the form of anti-Muslim actions (anti-social peer punishment), and the French government reacted by declaring a state of emergency and intensifying policing activities such as house searches and police stops. Here, I analyze these reactions and show that intensified policing, even though well intended, can be associated with considerable anti-social effects. Furthermore, I will show that the state of emergency was associated with certain dynamics that are worrisome for a democracy. Lastly, I will situate the findings in the conceptual distinction between institutional and peer punishment of behavioral science.

\subsubsection{Discussion}

The article departs from the position that institutional punishment is needed to curb anti-social peer punishment. The data which I used confirms that institutional punishment can reduce anti-social peer punishment in situations of social conflict. However, the article also shows that not only is peer punishment susceptible to antisociality, so too is institutional punishment. So, a society could end up trading antisocial peer punishment for anti-social institutional punishment.

Arguing in line with the Structure-Behavior Diagram, a state of emergency (SOE) has several effects. It decouples the principal-agent chains between citizens and politicians, and it allows anti-social side-effects of government actions to arise (i.e. mainly its security apparatus). The two-year French SOE brought a number of dynamics confirming this reasoning. The situation started with the terror attacks (antisocial peer punishment). Immediately after that, the government declared the SOE and intensified policing with anti-social side-effects. In parallel, society experienced antiMuslim attacks by non-Muslim citizens (anti-social peer punishment) in response to the attacks. This vengeful punishment faded out. However, the institutional punishment (policing) was also marked by anti-sociality (anti-social institutional punishment). Manifestations against the situation (pro-social peer punishment) were clamped down on by the police (anti-social institutional punishment). Over time, the government tried to reduce the anti-social effects of its activities, but more importantly, 
it reduced its communication about them and drew the public's attention away from the (negative) side-effects and toward the (positive) results. This interacted with increasing indifference from citizens and the press regarding the politicians' actions. In other words, the principals loosened their control over their political agents.

I could not answer the question of whether the anti-social aspects of the police campaign were a result of carelessness or even intended. Any intention could reflect a general anti-Muslim sentiment and a desire for revenge - the same feeling which caused the sparking of anti-Muslim peer punishment. More generally, further research is needed to examine whether the anti-sociality of institutional punishment can have a satisfactory and legitimacy-pretending effect on concealed peer punishment intentions (e.g. the desire for revenge). The motivation to write about policing (articles 3 and 4) results from the idea that security forces are one of the key punishment instruments of any government. Since good data on the negative effects of policing is hard to find, I took the opportunity of examining this case which offered a relatively good database; the same goes for the next article.

\subsection{Article 4: The Absence of Policing and the Political Economy of Contribution and Defection}

\subsubsection{Summary of the article}

Punishment is crucial to maintain cooperation and prevent defection in societies. Previous research has shown that, in small groups, public goods contribution drops (defection rises) and rises (defection drops) immediately when punishment disappears and reappears. I will discuss this effect for large groups (societies), the real-world environment, and the absence of policing. In contrast to small group experiments, there are delays in the change in contribution and defection levels following the disappearance and reappearance of punishment. The length of these delays varies and seems to depend on aspects such as trust, transparency, media behavior, and democratization level. All these aspects have politico-economic implications.

\subsubsection{Discussion}

In article 3, I analyze the consequences of institutional over-punishment - too much policing. Here, I discuss the sudden absence of institutional punishment - too little or no policing. Both have negative consequences on the pro-sociality of societies, their power asymmetries, and the free and democratic order. Not surprisingly, following the sudden absence of policing in the examined societies, defection levels rose immediately. Tendentially, the rise in defection was quicker than its decline once 
policing restarted. By contrast, the reactions of citizens were more delayed, and showed different patterns. These variations could have different reasons.

First, the defectors might be better informed about the (presence or absence) of policing activities than the citizens. Second, the citizens probably have a longer-term social contract with the government. They are aware that, from time to time, this social contract might require some investments and conditional "advance payments" to the government in order to continue functioning. However, this long-term contractual bond could also be based on a naïve form of trust in the government. In such a case, citizens would unconditionally continue to support the government, which increases the power asymmetries between the two.

Here, too, the quantity, quality, and completeness of the empirical data is challenging. Since the topic examines the alleged dysfunction of the political agents vis-à-vis their civilian agents, the former have no interest in providing objective data to the latter. The article shows that the delegation of power to institutional punishment (i.e. the government and its police) is delicate. Together with article 3 , it emphasizes that citizens must be attentive to ensure that there is no over- or under-punishment and no decline in institutional punishment's pro-sociality. Further, the reporting chain between citizens and their political agents must always function. In the last example of the article (Turkey), I show that the perdured absence of policing, the related contribution delays, and the changes in power asymmetries can bring a significant shift in pro-sociality (i.e. in the free and democratic order). 


\section{Conclusion}

\subsection{Findings}

Both research areas of this thesis, social hierarchies as well as democracies and authoritarianism, have been analyzed before by many scholars. However, there is little research combining these two dimensions in a single analysis. I create a model which systematically combines social hierarchies and the transitions between democracy and authoritarianism. With the Structure-Behavior Diagram, I lay the foundation for a combined analysis of verticality and sociality (Toelstede, 2020/1). I define these concepts theoretically, which enables countries to be categorized accordingly. For sociality, I use the of Cato Institute's Personal Freedom Indicator, which has shown good characteristics for the purpose. However, measuring the power asymmetries resulting from social hierarchies is more difficult. I therefore take government spending relative to the gross domestic product as an indicator of the government's size. The model and its underlying assumptions demonstrate that the verticality of societies influences their movements between democracy and authoritarianism. Further, the process of hierarchy formation and the type of social contract leading to this formation are different in pro-social and anti-social societies. The pattern is bottom-up in the former and top-down in the latter. Further, I show that institutional punishment is not always a stable alternative to peer punishment. There is sudden overand under-punishment (Toelstede, 2019/1 and 2020/2), as well as changes in the level of pro-sociality (Toelstede, 2019/1). Considering the power asymmetries inherent to institutional punishment, the consequences can be significant. In Toelstede (2019/1 and 2020/2), we see that these alterations brought a debilitation of the principal-agent chains between political agents and civilian principals.

I embed the path dependence model into the Structure-Behavior Diagram, which makes it possible to explain some of the dynamics in sociality and verticality. By using existing models and extending them, I isolate several path-creating mechanisms. These mechanisms foster the emergence of path dependences and structural lock-ins. I describe some regularities and dynamics within this political space. The first of these regularities is the positive correlation between pro-sociality and task escalation to the government. The higher the pro-sociality of the political system, the more citizens concede public goods tasks and, with them, power asymmetries to the government (Toelstede, 2020/1). Other relationships need to be explored. Together, they will form a landscape within the political space of the Structure-Behavior Diagram.

Democracies provide better socio-economic results for the people than nondemocracies (e.g. Barro, 1996; De Haan and Sturm, 2003; Acemoglu et al., 2019; Colagrossi et al., 2020). However, too many institutions can also limit the same. The paradoxical element is that some societies endorse ever more political institutions in 
response to socio-economic or political problems, although fewer institutions - not more - would provide more freedom for citizens. They might improve the welfare situation to a certain extent. However, they also weaken citizens' control over the political agents and increase the political agents' incentives for anti-social descent.

I have shown that societies which are prepared to trade personal freedom for higher socio-economic welfare by endorsing efficient statism delegate more public affairs to the government. Thus, they generate higher power asymmetries and move the society further upwards in $\mathrm{CH}$. At the same time, greater power asymmetries provide greater incentives to the political agents to abuse the situation and steer the societies to the right into DH. Power asymmetries allow political agents to create an 'uneven playing field' (Levitsky and Way, 2010/2), which further reinforces the asymmetries between, first, the different political agents and, second, the agents and the civilian principals. Information asymmetries between political agents and civilian principals provide a possibility for the agents to deceive the principals upon their intentioned anti-social descent. This movement leads to 'competitive authoritarianism' (Levitsky and Way, $2002,2010 / 1,2020)$ and can ultimately result in authoritarianism as such.

With all these arguments for a possible anti-social descent, why is it that many democratic societies remain democratic and what motivation do other societies have to become democratic? There is, first, the argument of better welfare results, which makes it attractive to remain or become a democracy. Second, the positive pressure of the international (democratic) community motivates non-democracies to become democracies and societies on a path of anti-social descent to turn around. However, this does not mean relying purely on the international community. As in all insurance contracts, if all insurants rely on the other insurants to bail them out, the insurance itself will collapse.

Third, peer punishment among (democratic) elites might prevent political leaders from anti-social descent, and does so in most cases. However, democratic elites could implement well-intentioned but ambiguous instruments which malicious politicians can abuse for their anti-social intentions. These ambiguous instruments can include data retention (Toelstede, 2019/2), increasing security forces, and introducing security laws in reaction to a terror attack (e.g. France after the 2015/2016 terror attacks; Toelstede 2019/1 and 2019/2). Further, the potential pro-social peer punishers in the (democratic) elite could have been sent to jail or dismissed from public office (e.g. in Turkey after the failed coup d'état in 2016; Caman, 2019; Yilmaz, 2019) and therefore put hors de combat. Additionally, studies about elite conformity indicate that the peer punishment among elites is not always driven by an absolute and universal prosociality understanding (see Sunstein, 2019 for an overview). Elite conformity can have a collusive character and, together with power asymmetries, represent a threat to democratic societies. More research in this area could help to provide a better understanding of when and how this aspect can be dangerous for democracies. 
Forth, the most effective instrument against the anti-social descent of political agents is probably civil unrest - once the problem of collective action is overcome. Antisocial institutional descent (CH-DH) fails if it comes at the price of losing citizens' support. It is the same revolutionary threat mechanism of weighing concession against disruption costs (e.g. De Mesquita and Smith, 2010; Klein and Regan, 2018; Toelstede, 2020/1) which triggers reforms in authoritarian regimes (DH-CH) and prevents CHs from descending into DHs. Lastly, the anti-social descent does not necessarily occur completely; the gradual descent toward the above-mentioned semi-democracies and semi-authoritarianism is also attractive to some elites. It allows the efficiency advantages of (what is left of) the democracy to be combined with the granted elite privileges of authoritarianism.

\subsection{Further research}

Apart from the findings, the approach offers a vast field for future research. I have shown a multitude of aspects in different areas of the model which can be explored in greater depth. The findings would support the refinement of the Structure-Behavior Diagram as a whole.

Beyond the relationship between public goods escalation and pro-sociality (Toelstede, 2020/1), I indicate at the end of the article the existence of other patterns in this political space. One of these could be the point of maximum anti-sociality of authoritarian regimes. This means that authoritarian regimes have a maximum antisociality in dependency of their power asymmetries which they should not pass to avoid any uprising and regime threat. This limit derives from the previously explained tolerance limit. Another pattern is the point of authoritarian break-down. In other words, the point where authoritarian structures melt and crumble (when moving topdown) or crystallize and consolidate (when moving bottom-up). Lastly, I assume that the transition between pro- and anti-sociality, including the implicit virtue reinterpretation (i.e. the definition of what will be rewarded and what will be punished), is distinct for different levels of power asymmetries. This is already part of some of my articles, but there is more to be explored.

Further research could also investigate the possibilities of transitions from $\mathrm{CH}$ to $\mathrm{SON}$, or from NW to DH. These diagonal movements imply simultaneous changes in sociality and power asymmetries. This, in turn, means a virtue reinterpretation and a change in the social rank order. This would also explain why democratic politicians $(\mathrm{CH})$ frequently warn about a potential slip into "chaos and individual egoism" (SON), and therefore endorse stronger democratic institutions (moving upwards in $\mathrm{CH}$ ). The argument from politicians that moving from $\mathrm{CH}$ toward $\mathrm{NW}$ would unavoidably end in SON could be based on the fact that they would lose power and privileges. Further, there are movements like $\mathrm{CH}$ to DH (democratic decline), DH to SON (authoritarian breakdown), and SON to DH (authoritarian re-emergence). Many of those movements 
might occur in rhythmic diagonal or triangular moves, as indicated in Toelstede (2020/1). Lastly, there are the transitions from anti- to pro-social societies (democratization), whether on a hierarchical level (DH to $\mathrm{CH}$ ) or a horizontal level (SON to NW). In both cases, the societies must consensually agree on new reward and punishment rules (i.e. virtue reinterpretation). This process is significantly different in hierarchical societies than in horizontal societies, due to the existent or absent power asymmetries and different group sizes.

I have shown a correlation between pro-sociality in a society and the level of vertical escalation measured by government expenditure relative to GDP. This indicator shows the size of the government, and is universally available at a reliable quality. However, as mentioned in the discussion (Toelstede, 2020/1), it ignores cultural differences, the constitutional and legal framework, civil participation, the relative spend on internal security forces, and other aspects. Therefore, the development of a power asymmetries indicator would help to specify the measurement of hierarchy strength in societies. Such an indicator must have the following characteristics. First, it is important that it only measures the power asymmetries and the ability to limit other individuals' degrees of freedom, and not the actual abuse. This needs to be measured using pro-sociality indicators. However, this distinction must consider that the mere threat of reward or punishment has an impact on the individual's behavior (e.g. Fehr and Gächter, 2002; Denant-Boemont et al., 2007; Masclet et al., 2013; Cimpeanu and Han, 2020) and therefore on the pro-sociality of societies. So, any potential power of political institutions (=institutional punishment threat) can have an impact on the citizen's personal freedom and then be measured by a pro-sociality indicator. Second, the nature of power asymmetries changes when societies move between democracy and authoritarianism. A proper power asymmetries indicator needs to reflect this change in the nature of power. Third, it would need to be applicable over a wide range of countries with differences in culture, religion, society, and economy.

There is another aspect which follows on from the correlation between the prosociality in a society and the level of vertical escalation (Toelstede, 2020/1). This correlation is the area where societies can achieve their optimum combination of personal freedom, self-determination, and socio-economic welfare. Societies which prefer personal freedom might be beneath this line; societies which are prepared to trade personal freedom for higher socio-economic welfare by endorsing efficient statism will be above this line. This is also the area of institutional economics that provides recommendations for the best institutional setup. Many societies are situated around that line. So, further research could focus on how to increase pro-sociality, personal freedom, and socio-economic efficiency (moving to the left) without increasing the power asymmetries between political agents and civilian principals (moving upwards). It could further analyze the presence of hierarchy-attenuating or enhancing attitudes (Bergh et al., 2020; Tesi et al., 2020). Lastly, one could ask why societies sometimes believe that a stronger state could provide them with a higher level of personal freedom and protect them from coercion. Is it a question of applying a 
positive or negative freedom concept? Or is this opinion maybe a result of the manipulation of citizens by their political agents who would benefit from any (further) vertical escalation? In Toelstede (2020/1), I argue that institutional punishment (coordination hierarchies) is more efficient than peer punishment (networks) (Halevy et al., 2011; Ronay et al., 2012). However, I speculate that the vertical escalation process does not have constant marginal welfare gains in relationship to the increases in power asymmetries. I expect that $\Delta$ welfare / $\triangle$ power-asymmetries $[\Delta w / \Delta P A]$ will decrease the more a society escalates public goods, meaning the higher a society moves in the SBD. This hypothesis draws support from the empirical finding that societies above the correlation line escalate public goods at a slower pace than those below (Toelstede, 2020/1). Further, I believe that $\Delta \mathrm{w} / \Delta \mathrm{PA}$ may become negative at a certain power asymmetries level. Apart from the increasing power asymmetries, there are structural lock-ins which I expect to be positively correlated to the level of antisociality and power asymmetries. Thus, these difficulties increase when moving in a north-eastern direction within the SBD. In this context, moderated networks (Toelstede, 2020/1) probably show the highest $\Delta \mathrm{w} / \Delta \mathrm{PA}$ values, meaning the highest welfare gains relative to the power asymmetries which the societies have to accept in return. All these aspects deserve the attention of further research.

I show that uncertainties, limited foresightedness, and political-economic aspects in hierarchical agencies can accompany path-creating mechanisms which, in turn, can move societies between democracy and authoritarianism. Further research in this area could help to provide a better understanding of the mechanisms of path dependence. As mentioned throughout the text, capital market behavior can also offer an interesting field for empirical behavioral studies under bounded rationality and political-economic tactics. Capital market data availability is of a higher quantity and quality, and is less distorted than behavioral data in hierarchical institutions, especially in nondemocracies. Certainly, some differences such as actors' anonymity and the absence of formal hierarchies need to be considered to make the results applicable to social hierarchies.

Further research would also improve our understanding of the motivational foundations of the interactions between civilian principals and political agents, the escalation process, and the control of political agents. Lastly, we need to better understand the potential and sudden decline in pro-sociality of security forces, meaning institutional punishment (Toelstede, 2019/1). 


\section{Acknowledgements}

Gustav Tinghög, my supervisor, and Ali Ahmed, my co-supervisor. Both guided me academically and supported me in many practical matters over the years.

Guido Toelstede and Renate Toelstede, my parents, who were always present with their unconditional support, their love and their advice.

Juliana Otero García, my wife, for tolerating the many endless evenings which I spent at my desk.

Peter Damberg and Stefan Svensson from Toyota Material Handling, for believing in this project from the first day.

Matthias Uhl, who encouraged me on many occasions to strive for a $\mathrm{PhD}$. 


\section{References}

Acemoglu, D., Naidu, S., Restrepo, P., \& Robinson, J. A. (2019). Democracy does cause growth. Journal of Political Economy, 127(1), 47-100.

Ahn, T. K., Isaac, R. M., \& Salmon, T. C. (2011). Rent seeking in groups. International Journal of Industrial Organization, 29(1), 116-125.

Alevy, J. E., Haigh, M. S., \& List, J. A. (2007). Information cascades: Evidence from a field experiment with financial market professionals. The Journal of Finance, 62(1), 151-180.

Almenberg, J., Dreber, A., Apicella, C., \& Rand, D. G. (2010). Third party reward and punishment: group size, efficiency and public goods. Psychology of Punishment, Nova Publishing.

Anderson, C. J. (2003). The psychology of doing nothing: forms of decision avoidance result from reason and emotion. Psychological Bulletin, 129(1), 139.

Arthur, W. B. (1989). Competing technologies, increasing returns, and lock-in by historical events. The Economic Journal, 116-131.

Arthur, W. B. (1994). Increasing returns and path dependence in the economy. University of Michigan Press.

Asch, S. E. (1955). Opinions and social pressure. Scientific American, 193(5), 31-35.

Axelrod, R. (1984/2006). The evolution of cooperation. Cambridge (MA).

Balliet, D., \& Van Lange, P. A. (2013). Trust, conflict, and cooperation: A metaanalysis.

Barro, R. J. (1996). Democracy and growth. Journal of Economic Growth, 1(1), 1-27.

Bénabou, R. (2012). Groupthink: Collective delusions in organizations and markets. The Review of Economic Studies, rds030.

Bergh, R., Davis, G. K., Hudson, S. K. T., \& Sidanius, J. Social Dominance Theory and Power Comparison.

Berlin, I. (1969). Two concepts of liberty. Berlin, i, 118(1969), 172.

Besley, T. (2006). Principled agents?: The political economy of good government. Oxford University Press on Demand.

Besley, T., \& Persson, T. (2019). Democratic values and institutions. American Economic Review: Insights, 1(1), 59-76.

Beyer, J. (2010). The same or not the same - on the variety of mechanisms of path dependence. International Journal of Social Sciences, 5(1), 1-11.

Boddy, C. R. (2005). The implications of corporate psychopaths for business and society: An initial examination and a call to arms. Australasian Journal of Business and Behavioural Sciences, 1(2), 30-40. 
Bond, R., \& Smith, P. B. (1996). Culture and conformity: A meta-analysis of studies using Asch's (1952b, 1956) line judgment task. Psychological Bulletin, 119(1), 111.

Bourdieu, P. (1984). Espace social et genèse des "classes". Actes de la recherche en sciences sociales, 52(1), 3-14.

Botelho, A., Harrison, G. W., Pinto, L. M. C., Ross, D., \& Rutström, E. E. (2019). Endogenous Choice of Institutional Punishment Mechanisms to Promote Social Cooperation. CEAR Working Paper 2019-04.

Bowles, S., \& Gintis, H. (2011). A cooperative species: Human reciprocity and its evolution. Princeton University Press.

Boyd, R., Gintis, H., Bowles, S., \& Richerson, P. J. (2003). The evolution of altruistic punishment. Proceedings of the National Academy of Sciences, 100(6), 35313535 .

Bryson, J. J., Mitchell, J., Powers, S. T., \& Sylwester, K. (2014). Understanding and addressing cultural variation in costly antisocial punishment (pp. 201-222). Springer New York.

Casari, M., \& Luini, L. (2009). Cooperation under alternative punishment institutions: An experiment. Journal of Economic Behavior \& Organization, 71(2), 273-282.

Cashdan, E., \& Steele, M. (2013). Pathogen prevalence, group bias, and collectivism in the standard cross-cultural sample. Human Nature, 24(1), 59-75.

CATO (2017) The Human Freedom Index 2017. Washington, DC: CATO Institute. Available at: https://www.cato.org/human-freedom-index-new (accessed December 14, 2018).

CATO (2018) The Human Freedom Index 2018. Washington, DC: CATO Institute. Available at: https://www.cato.org/human-freedom-index-new (accessed December 14, 2018).

Chaloemtiarana, T. (2007). Thailand: The politics of despotic paternalism (No. 42). SEAP Publications.

Chamley, C., \& Gale, D. (1994). Information revelation and strategic delay in a model of investment. Econometrica: Journal of the Econometric Society, 1065-1085.

Cimpeanu, T., \& Han, T. A. (2020, May). Fear of Punishment Promotes the Emergence of Cooperation and Enhanced Social Welfare in Social Dilemmas. In Proceedings of the 19th International Conference on Autonomous Agents and MultiAgent Systems (pp. 1819-1821).

Cipriani, M., \& Guarino, A. (2005). Herd behavior in a laboratory financial market. American Economic Review, 95(5), 1427-1443.

Clark, C. (2012). The sleepwalkers: How Europe went to war in 1914. Penguin UK.

Colagrossi, M., Rossignoli, D., \& Maggioni, M. A. (2020). Does democracy cause growth? A meta-analysis (of 2000 regressions). European Journal of Political Economy, 61, 101824.

Cowen, T. (2005). Self-deception as the root of political failure. Public Choice, 124(34), 437-451. 
Cushman, F. (2015). Punishment in humans: From intuitions to institutions. Philosophy Compass, 10(2), 117-133.

Dannenberg, A., \& Gallier, C. (2019). The choice of institutions to solve cooperation problems: a survey of experimental research. Experimental Economics, 1-34.

Dasgupta, A. (2007). Coordination and delay in global games. Journal of Economic Theory, 134(1), 195-225.

David, P. A. (1985). Clio and the Economics of QWERTY. The American Economic Review, 75(2), 332-337.

Demange, G. (2004). On group stability in hierarchies and networks. Journal of Political Economy, 112(4), 754-778.

Denant-Boemont, L., Masclet, D., \& Noussair, C. N. (2007). Punishment, counterpunishment and sanction enforcement in a social dilemma experiment. Economic Theory, 33(1), 145-167.

De Haan, J., \& Sturm, J. E. (2003). Does more democracy lead to greater economic freedom? New evidence for developing countries. European Journal of Political Economy, 19(3), 547-563.

De Luca, G., Litina, A., \& Sekeris, P. G. (2015). Growth-friendly dictatorships. Journal of Comparative Economics, 43(1), 98-111.

De Mesquita, B. B., \& Smith, A. (2010). Leader survival, revolutions, and the nature of government finance. American Journal of Political Science, 54(4), 936-950.

De Mesquita, B. B., Morrow, J. D., Siverson, R. M., \& Smith, A. (2002). Political institutions, policy choice and the survival of leaders. British Journal of Political Science, 32(04), 559-590.

De Tocqueville (2011). Democracy in America Vol. I. Create Space Independent Publishing Platform.

Delsol, C. (2015). L’État subsidiaire. 2nd edition, Paris.

Dubreuil, Benoît (2010). Human Evolution and the Origins of Hierarchies. New York.

Edsall, Thomas B. (2014). How Much Do Our Genes Influence Our Political Beliefs? The International New York Times. July 8, 2014. Source: https://nyti.ms/1mxhC29

Elder-Vass, D. (2010). The causal power of social structures: emergence, structure and agency. Cambridge University Press.

Endo, K. (1992). The Principle of Subsidiarity: From Johannes Althusius to Jacques Delors. Bull. CE, 12, 75.

Enke, B., \& Zimmermann, F. (2019). Correlation neglect in belief formation. The Review of Economic Studies, 86(1), 313-332.

Farrow, T. F., Jones, S. C., Kaylor-Hughes, C. J., Wilkinson, I. D., Woodruff, P. W., Hunter, M. D., \& Spence, S. A. (2011). Higher or lower? The functional anatomy of perceived allocentric social hierarchies. Neuroimage, 57(4), 1552-1560. 
Fast, N. J., Sivanathan, N., Mayer, N. D., \& Galinsky, A. D. (2012). Power and overconfident decision-making. Organizational Behavior and Human Decision Processes, 117(2), 249-260.

Fehl, K., Sommerfeld, R. D., Semmann, D., Krambeck, H. J., \& Milinski, M. (2012). I dare you to punish me-vendettas in games of cooperation. PloS one, 7(9), e45093.

Fehr, E., \& Fischbacher, U. (2004). Third-party punishment and social norms. Evolution and Human Behavior, 25(2), 63-87.

Fehr, E., \& Gächter, S. (1999/2000). Cooperation and punishment in public goods experiments. American Economic Review, 980-994. (The article was published in 2000, but there is also a more comprehensive version of the article from 1999 available on the internet.)

Fehr, E., \& Gächter, S. (2002). Altruistic punishment in humans. Nature, 415(6868), 137-140.

Fehr, E., \& Schmidt, K. M. (1999). A theory of fairness, competition, and cooperation. The Quarterly Journal of Economics, 114(3), 817-868.

Fincher, C. L., Thornhill, R., Murray, D. R., \& Schaller, M. (2008). Pathogen prevalence predicts human cross-cultural variability in individualism/collectivism. Proceedings of the Royal Society of London B: Biological Sciences, 275(1640), 1279-1285.

Fischer, S., Grechenig, K. R., \& Meier, N. (2013). Cooperation under punishment: Imperfect information destroys it and centralizing punishment does not help. MPI Collective Goods Preprint, (2013/06).

Føllesdal, A. (1998). Subsidiarity. Journal of Political Philosophy, 6(2), 231-259.

Føllesdal, A. (2014). Competing conceptions of subsidiarity.

Forrat, N. (2012). The authoritarian welfare state: a marginalized concept. Comparative Historical Social Science Working Paper Series, (12-005).

Friesen, J. P., Kay, A. C., Eibach, R. P., \& Galinsky, A. D. (2014). Seeking structure in social organization: Compensatory control and the psychological advantages of hierarchy. Journal of Personality and Social Psychology, 106(4), 590.

Gächter, S., \& Herrmann, B. (2009). Reciprocity, culture and human cooperation: previous insights and a new cross-cultural experiment. Philosophical Transactions of the Royal Society B: Biological Sciences, 364(1518), 791-806.

Gächter, S., \& Herrmann, B. (2011). The limits of self-governance when cooperators get punished: Experimental evidence from urban and rural Russia. European Economic Review, 55(2), 193-210.

Gächter, S., Herrmann, B., \& Thöni, C. (2010). Culture and cooperation. Philosophical Transactions of the Royal Society of London B: Biological Sciences, 365(1553), 2651-2661.

Gardels, Nathan (2012). Medios sociales y democracia deliberativa. [Social Media and deliberative democracy.] El País (Madrid). March 21, 2012. Source: http://elpais.com/elpais/2012/03/15/opinion/1331811901_336964.html 
Gennaioli, N., Shleifer, A., \& Vishny, R. (2015). Neglected risks: The psychology of financial crises. American Economic Review, 105(5), 310-14.

Gintis, H. (2013). 2. Altruistic reciprocity. Handbook on the Economics of Philanthropy, Reciprocity and Social Enterprise, 20.

Graham, J., Haidt, J., \& Nosek, B. A. (2009). Liberals and conservatives rely on different sets of moral foundations. Journal of Personality and Social Psychology, 96(5), 1029.

Grossman, P. J., \& Komai, M. (2013). Within and Across Class Envy: Anti-Social Behaviour in Hierarchical Groups (No. 02-13). Monash University, Department of Economics.

Grossman, Z., \& Van der Weele, J. J. (2017). Self-image and willful ignorance in social decisions. Journal of the European Economic Association, 15(1), 173-217.

Gupte, M., Shankar, P., Li, J., Muthukrishnan, S., \& Iftode, L. (2011, March). Finding hierarchy in directed online social networks. In Proceedings of the 20th International Conference on World Wide Web (pp. 557-566). ACM.

Gürerk, Ö., Irlenbusch, B., \& Rockenbach, B. (2006). The competitive advantage of sanctioning institutions. Science, 312(5770), 108-111.

Habermas, J. (2009). Diskursethik (Vol. 3). Suhrkamp.

Halevy, N., Chou, E. Y., \& Galinsky, A. D. (2011). A functional model of hierarchy: Why, how, and when vertical differentiation enhances group performance. Organizational Psychology Review, 1(1), 32-52.

Halevy, N., Chou, E. Y., Galinsky, A. D., \& Murnighan, J. K. (2012). When hierarchy wins evidence from the national basketball association. Social Psychological and Personality Science, 3(4), 398-406.

Han, Byung-Chul (2005). Was ist Macht? Stuttgart.

Harms, P. D., Wood, D., Landay, K., Lester, P. B., \& Lester, G. V. (2018). Autocratic leaders and authoritarian followers revisited: A review and agenda for the future. The Leadership Quarterly, 29(1), 105-122.

Hauser, O. P., Nowak, M. A., \& Rand, D. G. (2014). Punishment does not promote cooperation under exploration dynamics when anti-social punishment is possible. Journal of Theoretical Biology, 360, 163-171.

Hayek, F. A. (1944/2007). The Road to Serfdom: Text and Documents: The Definitive Edition. The University of Chicago Press, Routledge, London.

Henningham, J. P. (1996). A 12-item scale of social conservatism. Personality and Individual Differences, 20(4), 517-519.

Henrich, J., Boyd, R., Bowles, S., Camerer, C., Fehr, E., Gintis, H., ... \& Henrich, N. S. (2005). "Economic man" in cross-cultural perspective: Behavioral experiments in 15 small-scale societies. Behavioral and Brain Sciences, 28(06), 795-815.

Henrich, J., Heine, S. J., \& Norenzayan, A. (2010). The weirdest people in the world? Behavioral and Brain Sciences, 33(2-3), 61-83. 
Henrich, J., McElreath, R., Barr, A., Ensminger, J., Barrett, C., Bolyanatz, A., ... \& Ziker, J. (2006). Costly punishment across human societies. Science, 312(5781), 1767-1770.

Herrmann, B., Thöni, C., \& Gächter, S. (2008). Antisocial punishment across societies. Science, 319(5868), 1362-1367.

Hinsz, V. B., Tindale, R. S., \& Nagao, D. H. (2008). Accentuation of information processes and biases in group judgments integrating base-rate and case-specific information. Journal of Experimental Social Psychology, 44(1), 116-126.

Hirshleifer, D. (2015). Behavioral finance. Annual Review of Financial Economics, 7, 133-159.

Hirshleifer, D., \& Hong Teoh, S. (2003). Herd behaviour and cascading in capital markets: A review and synthesis. European Financial Management, 9(1), 25-66.

Hirshleifer, D., \& Teoh, S. H. (2009). Thought and behavior contagion in capital markets. In Handbook of financial markets: Dynamics and evolution (pp. 1-56). North-Holland.

Hobbes, T. (1985). Leviathan. MacPherson CB, ed., London.

Hoff, K., Kshetramade, M., \& Fehr, E. (2011). Caste and punishment: the legacy of caste culture in norm enforcement. The Economic Journal, 121(556), F449-F475.

Hutcheson, F. (1729). An Inquiry into the Original of our Ideas of Beauty and Virtue... The second edition, corrected and enlarg'd.

Inglehart, R., \& Welzel, C. (2005). Modernization, cultural change, and democracy: The human development sequence. Cambridge University Press.

Irwin, K., \& Horne, C. (2013). A normative explanation of antisocial punishment. Social Science Research, 42(2), 562-570.

Isakov, A., \& Rand, D. G. (2012). The evolution of coercive institutional punishment. Dynamic Games and Applications, 2(1), 97-109.

Janis, I. L. (2008). Groupthink. IEEE Engineering Management Review, 36(1), 36.

Judge, T. A., Piccolo, R. F., \& Kosalka, T. (2009). The bright and dark sides of leader traits: A review and theoretical extension of the leader trait paradigm. The Leadership Quarterly, 20(6), 855-875.

Kahneman, D. (2011). Thinking, fast and slow. Macmillan.

Karl, T. L. (2007). Oil-led development: social, political, and economic consequences. Encyclopedia of energy, 4, 661-672.

Kesler, C. R. (2003). The federalist papers. Penguin.

Ketcham, R. (2003). The anti-federalist papers and the constitutional convention debates. Penguin.

Kilduff, G. J., Elfenbein, H. A., \& Staw, B. M. (2010). The psychology of rivalry: A relationally dependent analysis of competition. Academy of Management Journal, 53(5), 943-969. 
Kilduff, G., Galinsky, A., Gallo, E., \& Reade, J. (2012, June). Whatever it takes: Rivalry and unethical behavior. In Intl. Association for Conflict Management, IACM 25th Annual Conference (pp. 12-14).

Klein, G. R., \& Regan, P. M. (2018). Dynamics of Political Protests. International Organization, 72(2), 485.

Krebs, D. L., \& Denton, K. (2005). Toward a more pragmatic approach to morality: a critical evaluation of Kohlberg's model. Psychological Review, 112(3), 629.

Leibbrandt, A., \& López-Pérez, R. (2012). An exploration of third and second party punishment in ten simple games. Journal of Economic Behavior \& Organization, 84(3), 753-766.

Levitsky, S., \& Way, L. A. (2002). Elections without democracy: The rise of competitive authoritarianism. Journal of Democracy, 13(2), 51-65.

Levitsky, S., \& Way, L. A. (2010/1). Competitive authoritarianism: Hybrid regimes after the Cold War. Cambridge University Press.

Levitsky, S., \& Way, L. A. (2010/2). Democracy's Past and Future: Why Democracy Needs a Level Playing Field. Journal of Democracy, 21(1), 57-68.

Levitsky, S., \& Way, L. (2020). The New Competitive Authoritarianism. Journal of Democracy, 51-65.

Liebowitz, S. J., \& Margolis, S. E. (1995). Path dependence, lock-in, and history. JL Econ. \& Org., 11, 205.

Lim, W., \& Zhang, J. (2020). Endogenous Authority and Enforcement in Public Goods Games. The BE Journal of Theoretical Economics.

Lorenz, J., Rauhut, H., Schweitzer, F., \& Helbing, D. (2011). How social influence can undermine the wisdom of crowd effect. Proceedings of the National Academy of Sciences, 108(22), 9020-9025.

Luhrmann, T.M. (2014). Wheat People vs. Rice People. Why Are Some Cultures More Individualistic Than Others? The International New York Times. December 3, 2014. Source: http://nyti.ms/1yPwygV

Lynch, K. (2016). Willful ignorance and self-deception. Philosophical Studies, 173(2), 505-523.

Magee, J. C., \& Langner, C. A. (2008). How personalized and socialized power motivation facilitate antisocial and prosocial decision-making. Journal of Research in Personality, 42(6), 1547-1559.

Marcin, I., Robalo, P., \& Tausch, F. (2019). Institutional endogeneity and third-party punishment in social dilemmas. Journal of Economic Behavior \& Organization, $161,243-264$.

Martin, A. (2010). The Principle of Subsidiarity and Institutional Predispositions: Do the European Parliament, the German Bundestag, and the Bavarian Landtag Define Subsidiarity Differently?

Masclet, D., Noussair, C. N., \& Villeval, M. C. (2013). Threat and punishment in public good experiments. Economic Inquiry, 51(2), 1421-1441. 
Matsumoto, D. (2007). Individual and cultural differences on status differentiation: The status differentiation scale. Journal of Cross-Cultural Psychology, 38(4), 413-431.

McNulty, S. (2012). An unlikely success: Peru's top-down participatory budgeting experience. Journal of Public Deliberation, 8(2), 4.

Murray, D. (2013). The implications of disease threat for attitudes, behavior, and culture. Doctoral Thesis at the University of British Columbia, Vancouver.

Murray, D. R., Schaller, M., \& Suedfeld, P. (2013). Pathogens and politics: Further evidence that parasite prevalence predicts authoritarianism. PloS One, 8(5), e62275.

Muthukrishna, M., Heine, S. J., Toyakawa, W., Hamamura, T., Kameda, T., \& Henrich, J. (2014). Overconfidence is universal? Depends on what you mean. Manuscript submitted for publication.

Navia, P. (2008). Top-down and bottom-up democracy in Latin America: The case of Bachelet in Chile. Stockholm Review of Latin American Studies, 3(December), 119-130.

Nicklisch, A., Grechenig, K., \& Thöni, C. (2016). Information-sensitive leviathans. Journal of Public Economics, 144, 1-13.

Nikiforakis, N. (2008). Punishment and counter-punishment in public good games: Can we really govern ourselves? Journal of Public Economics, 92(1), 91-112.

Nikiforakis, N., \& Engelmann, D. (2011). Altruistic punishment and the threat of feuds. Journal of Economic Behavior \& Organization, 78(3), 319-332.

Nikiforakis, N., \& Mitchell, H. (2014). Mixing the carrots with the sticks: Third party punishment and reward. Experimental Economics, 17(1), 1-23.

Nikiforakis, N., Normann, H. T., \& Wallace, B. (2010). Asymmetric enforcement of cooperation in a social dilemma. Southern Economic Journal, 76(3), 638-659.

Ordabayeva, N., \& Fernandes, D. (2018). Better or different? How political ideology shapes preferences for differentiation in the social hierarchy. Journal of Consumer Research, 45(2), 227-250.

Ostrom, E. (1990). Governing the commons: The evolution of institutions for collective action. Cambridge University Press.

Osumi, T., \& Ohira, H. (2010). The positive side of psychopathy: Emotional detachment in psychopathy and rational decision-making in the ultimatum game. Personality and Individual Differences, 49(5), 451-456.

Owen, C. (2020). Participatory Authoritarianism: From Bureaucratic Transformation to Civic Participation in Russia and China.

Petermann, A. (2010). Pfadabhängigkeit und Hierarchie: zur Durchsetzungskraft von selbstverstärkenden Effekten in hierarchischen Organisationen (Doctoral dissertation, Berlin, Freie Universität).

Pfeffer, J. (2013). You're still the same: Why theories of power hold over time and across contexts. The Academy of Management Perspectives, 27(4), 269-280. 
Pieterse, A. N., Hollenbeck, J. R., van Knippenberg, D., Spitzmüller, M., Dimotakis, N., Karam, E. P., \& Sleesman, D. J. (2019). Hierarchical leadership versus selfmanagement in teams: Goal orientation diversity as moderator of their relative effectiveness. The Leadership Quarterly, 30(6), 101343.

Pinker, S. (2011). The better angels of our nature: The decline of violence in history and its causes. Penguin UK.

Pontier, J. M. (1986). La subsidiarité en droit administratif.

Rand, D. G., Armao IV, J. J., Nakamaru, M., \& Ohtsuki, H. (2010). Anti-social punishment can prevent the co-evolution of punishment and cooperation. Journal of Theoretical Biology, 265(4), 624-632.

Reit, E. S., \& Halevy, N. (2020). Managing hierarchy's functions and dysfunctions: a relational perspective on leadership and followership. Current Opinion in Psychology, 33, 126-130.

Robertson, S. A., Datu, J. A. D., Brawley, A. M., Pury, C. L., \& Mateo, N. J. (2016). The Dark Triad and social behavior: The influence of self-construal and power distance. Personality and Individual Differences, 98, 69-74.

Ronay, R., Greenaway, K., Anicich, E. M., \& Galinsky, A. D. (2012). The path to glory is paved with hierarchy when hierarchical differentiation increases group effectiveness. Psychological Science, 23(6), 669-677.

Rousseau, J. J. (1766). Contrat social: ou principes du droit politique.

Schippers, M. C., Edmondson, A. C., \& West, M. A. (2014). Team Reflexivity as an Antidote to Team Information-Processing Failures. Small Group Research, 45(6), 731-769.

Scully, G. W. (1997). Democide and genocide as rent-seeking activities. Public Choice, 93(1-2), 77-97.

Searle, J. R. (1995). The construction of social reality. Simon and Schuster.

Searle, J. R. (2005). What is an institution? Journal of Institutional Economics, 1(1), $1-22$.

Searle, J. (2010). Making the social world: The structure of human civilization. Oxford University Press.

Sigmund, K., De Silva, H., Traulsen, A., \& Hauert, C. (2010). Social learning promotes institutions for governing the commons. Nature, 466(7308), 861-863.

Smith, A. (2010). The theory of moral sentiments. Penguin.

Smith, G. (2009). Democratic innovations: Designing institutions for citizen participation. Cambridge University Press.

Smith, M. B., Hill, A. D., Wallace, J. C., Recendes, T., \& Judge, T. A. (2018). Upsides to dark and downsides to bright personality: A multidomain review and future research agenda. Journal of Management, 44(1), 191-217.

Sterelny, K., Joyce, R., Calcott, B., \& Fraser, B. (Eds.). (2013). Cooperation and its evolution. MIT Press. 
Sunstein, C. R. (2014). Why nudge?: The politics of libertarian paternalism. Yale University Press.

Sunstein, C. R. (2019). Conformity: the power of social influences. NYU Press.

Svolik, M. W. (2012). The politics of authoritarian rule. Cambridge University Press.

Sydow, J., Schreyögg, G., \& Koch, J. (2009). Organizational path dependence: Opening the black box. Academy of Management Review, 34(4), 689-709.

Sydow, J., Schreyögg, G., \& Koch, J. (2020). On the theory of organizational path dependence: Clarifications, replies to objections, and extensions. Academy of Management Review, (ja).

Sylwester, K., Herrmann, B., \& Bryson, J. J. (2013). Homo homini lupus? Explaining antisocial punishment. Journal of Neuroscience, Psychology, and Economics, 6(3), 167.

Szolnoki, A., \& Perc, M. (2015). Antisocial pool rewarding does not deter public cooperation. In Proc. R. Soc. B (Vol. 282, No. 1816, p. 20151975). The Royal Society.

Taleb, N. N. (2007). The black swan: The impact of the highly improbable (Vol. 2). Random House.

Tan, F., \& Xiao, E. (2012). Peer punishment with third-party approval in a social dilemma game. Economics Letters, 117(3), 589-591.

Tan, F., \& Xiao, E. (2018). Third-party punishment: Retribution or deterrence? Journal of Economic Psychology, 67, 34-46.

Tesi, A., Pratto, F., Pierro, A., \& Aiello, A. (2020). Group dominance in hierarchyattenuating and hierarchy-enhancing organizations: The role of social dominance orientation, need for cognitive closure, and power tactics in a personenvironment (mis)fit perspective. Group Dynamics: Theory, Research, and Practice, 24(2), 102.

Teece, D. J., Pisano, G., \& Shuen, A. (1997). Dynamic capabilities and strategic management. Strategic Management Journal, 18(7), 509-533.

Tharoor, Ishaan (2014). 4 reasons Hong Kong's protests failed (and 4 reasons they didn't). The Washington Post. October 8, 2014. Source: http://www.washingtonpost.com/blogs/worldviews/wp/2014/10/08/4-reasonshong-kongs-protests-failed-and-4-reasons-they-didnt/

Tiedens, L. Z., \& Fragale, A. R. (2003). Power moves: complementarity in dominant and submissive nonverbal behavior. Journal of Personality and Social Psychology, 84(3), 558.

Tiedens, L. Z., Unzueta, M. M., \& Young, M. J. (2007). An unconscious desire for hierarchy? The motivated perception of dominance complementarity in task partners. Journal of Personality and Social Psychology, 93(3), 402.

Toelstede, B. (2019/1). Democracy interrupted: the anti-social side of intensified policing. Democracy and Security, 15(2), 137-149. 
Toelstede, B. (2019/2). How path-creating mechanisms and structural lock-ins make societies drift from democracy to authoritarianism. Rationality and Society, 1043463119840040 .

Toelstede, B. (2020/1) Social Hierarchies in Democracies and Authoritarianism: The Balance between Power Asymmetries and Principal-Agent Chains, Rationality and Society, 1043463120904051.

Toelstede, B. (2020/2). The Absence of Policing and the Political Economy of Contribution and Defection. Democracy and Security, 1-20.

Traulsen, A., Röhl, T., \& Milinski, M. (2012, September). An economic experiment reveals that humans prefer pool punishment to maintain the commons. In Proc. R. Soc. B (Vol. 279, No. 1743, pp. 3716-3721). The Royal Society.

Tversky, A., \& Kahneman, D. (1981). Evidential impact of base rates (No. TR-4). Stanford Univ. CA, Dept. of Psychology.

Tversky, A., \& Kahneman, D. (1981). The framing of decisions and the psychology of choice. Science, 211(4481), 453-458.

Tversky, A., \& Kahneman, D. (1983). Extensional versus intuitive reasoning: The conjunction fallacy in probability judgment. Psychological Review, 90(4), 293.

Tuomela, R. (2013). Social ontology: Collective intentionality and group agents. Oxford University Press.

Visser, M. (2006). Welfare implications of peer punishment in unequal societies. Working Papers in Economics, (218).

Vize, C. E., Lynam, D. R., Collison, K. L., \& Miller, J. D. (2018). Differences among dark triad components: A meta-analytic investigation. Personality Disorders: Theory, Research, and Treatment, 9(2), 101.

Voland, E., \& Schiefenhövel, W. (2009). The biological evolution of religious mind and behavior. Springer.

Von Hippel, W., \& Trivers, R. (2011). The evolution and psychology of selfdeception. Behavioral and Brain Sciences, 34(1), 1.

Watrin, C. (2003). On the political economy of the subsidiarity principle. Journal des économistes et des études humaines, 13(2).

Watts, A. L., Lilienfeld, S. O., Smith, S. F., Miller, J. D., Campbell, W. K., Waldman, I. D., ... \& Faschingbauer, T. J. (2013). The double-edged sword of grandiose narcissism implications for successful and unsuccessful leadership among US Presidents. Psychological Science, 24(12), 2379-2389.

Weber, M. (2006). Wirtschaft und Gesellschaft. Paderborn (Germany).

Wenzel, M., Okimoto, T. G., Feather, N. T., \& Platow, M. J. (2008). Retributive and restorative justice. Law and Human Behavior, 32(5), 375-389.

Williamson, O. E. (1975). Markets and hierarchies. New York, 2630.

Wright, J., Frantz, E., \& Geddes, B. (2015). Oil and autocratic regime survival. British Journal of Political Science, 45(02), 287-306. 
Xiao, E. (2013). Profit-seeking punishment corrupts norm obedience. Games and Economic Behavior, 77(1), 321-344.

Yilmaz, I. (2019). The Rise and Fall of Democracy in Turkey. Available at SSRN 3575701 .

Zacharakis, A. L., \& Shepherd, D. A. (2001). The nature of information and overconfidence on venture capitalists' decision making. Journal of Business Venturing, 16(4), 311-332. 


\section{The articles}





\section{Papers}

The papers associated with this thesis have been removed for copyright reasons. For more details about these see:

http://urn.kb.se/resolve?urn=urn:nbn:se:liu:diva-171091 


\section{FACULTY OF ARTS AND SCIENCES}

Linköping Studies in Arts and Sciences

Dissertation No. 797

Department of Management and Engineering

Linköping University

SE-581 83 Linköping, Sweden

www.liu.se
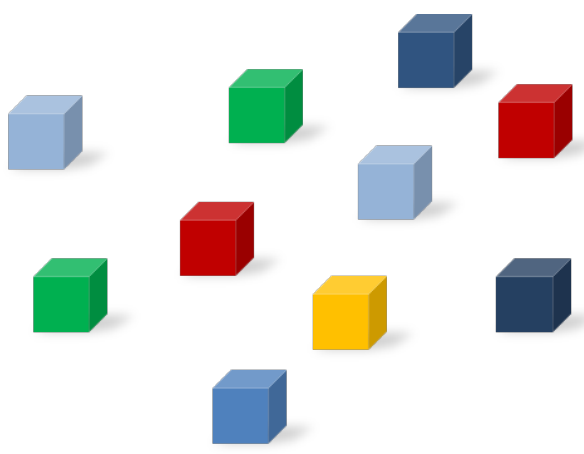